National

Academy

of

Sciences

National Research Council

NUCLEAR SCIENCE SERIES

\title{
The Radiochemistry of Fluorine, Chlorine, Bromine and lodine
}




\section{COMMITTEE ON NUCLEAR SCIENCE}

L. F. CURTISS, Chairman

National Bureau of Standards
ROBLEY D. EVANS, Vice Chairman

Massachusetts Institute of Technology

J. A. DeJUREN, Secretary

Westinghouse Electric Corporation

\section{H. J. CURTIS \\ Brookhaven National Laboratory \\ SAMUEL EPSTEIN \\ Callfornla Instltute of Technology \\ HERBERT GOLDSTEIN \\ Nuclear Development Corporation of \\ America}

H. J. GOMBERG

University of Michigan

E. D. KLEMA

Northwestern University

ROBERT L. PLATZMAN

Argonne National Laboratory

\section{G. G. MANOV}

Tracerlab, Inc.

W. WAYNE MEINKE

University of Michlgan

A. H. SNELL

Oak Ridge National Laboratory

E. A. UEHLING

University of Washington

D. M. VAN PATTER

Bartol Research Foundation

\section{LIAISON MEMBERS}

PAUL C. AEBERSOLD

Atomic Energy Commission

J. HOW ARD MCMILLEN

National Science Foundation
W. D. URRY

U. S. Air Force

WILLIAM E. WRIGHT

Office of Naval Research

\section{SUBCOMMITTEE ON RADIOCHEMISTRY}

W. WAYNE MEINKE, Chairman

University of Michigan

NATHAN BALLOU

Navy Radiological Defense Laboratory

GREGORY R. CHOPPIN

Florida State University

GEORGE A. COWAN

Los Alamos Scientific Laboratory

ARTHUR W. FAIRHALL

University of Washington

HARMON FINSTON

Brookhaven National Laboratory
EARL HYDE

University of California (Berkeley)

HAROLD KIRBY

Mound Laboratory

GEORGE LEDDICOTTE:

Oak Ridge National Laboratury

ELLIS P. STEINBERG

Argonne National Laboratory

PETER C. STEVENSON

University of California (Livermore)

LEO YAFFE

McGill University 


\section{DISCLAIMER}

This report was prepared as an account of work sponsored by an agency of the United States Government. Neither the United States Government nor any agency Thereof, nor any of their employees, makes any warranty, express or implied, or assumes any legal liability or responsibility for the accuracy, completeness, or usefulness of any information, apparatus, product, or process disclosed, or represents that its use would not infringe privately owned rights. Reference herein to any specific commercial product, process, or service by trade name, trademark, manufacturer, or otherwise does not necessarily constitute or imply its endorsement, recommendation, or favoring by the United States Government or any agency thereof. The views and opinions of authors expressed herein do not necessarily state or reflect those of the United States Government or any agency thereof. 


\section{DISCLAIMER}

Portions of this document may be illegible in electronic image products. Images are produced from the best available original document. 


\title{
The Radiochemistry of Fluorine, Chlorine, Bromine and lodine
}

\author{
By JACOB KLEINBERG and G. A. COWAN \\ University of California \\ Los Alamos Scientific Laboratory \\ Los Alamos, New Mexico \\ January 1960
}

Subcommittee on Radiochemistry

National Academy of Sciences - National Research Council

Printed in USA. Price \$0.50. Available from the office of Technical Services, Department of Commerce, Washington 25, D. C. 
-

,

- 


\section{FOREWORD}

The Subcormittee on Radiochenistry is one of a number of subcomittees working under the Committee on Nuclear Science within the National Academy of Sciences - National Research Council. Its members represent government, industrial, and university laboratories in the areas of nuclear chemistry and analytical chemistry.

The Subcomittee has concermed itself with those areas of nuclear science which involve the chemist, such as the collection and distribution of radiochemical procedures, the establishment of specifications for radiochemically pure reagents, the problems of stockpiling uncontaminated materials, the availability of cyclotron time for service irradiations, the place of radiochemistry in the undergraduate college program, etc.

This series of monographs has grown out of the need for up-to-date compilations of radiochemical information and procedures. The Subcomittee has endeavored to present a series which will be of maximum use to the working scientist and which contains the latest available information. Each monograph collects in one volume the pertinent information required for radiochemical work with an individual element or a group of closely related elements.

An expert in the radiochemistry of the particular element has written the monograph, following a standard format developed by the Subcomittee. The Atomic Energy Commission has sponsored the printing of the series.

The Subcomittee is confident these publications will be useful not only to the radiochemist but also to the research worker in other fields such as physics, biochemistry or medicine who wishes to use radiochemical techniques to solve a specific problem. 
-

, 


\section{CONTENTS}

I. General References to the Inorganic and Analytical Chemistry of the Hrlogens.

II. Table of Isotopes of Fluorine, Chlorine, Bromine and Iodine.

III. A Review of Some Aspects of Halogen Chemistry of Interest to Radiochemists.

IV. Collection of Radiochemical Procedures for Fluorine, Chlorine, Bromine, and Iodine. 


\section{INTRODUCTION}

This volume which deals with the radiochemistry of fluorine, chlorine, bromine and iodine is one of a sexies of monographs on radiochemistry of the elements. There is included a review of the nuclear and chemical features of particular interest to the radiochemist, a discussion of problems of dissolution of a sample and counting techniques, and finally, a collection of radiochemical procedures for the elements as found in the Iiterature.

The series of monographs will cover all elements for which radiochemical procedures are pertinent. Plans include revision of the monograph periodically as new techniques and procedures warrant. The reader is therefore encouraged to call to the attention of the author any published or unpublished material on the radiochemistry of fluorine, chlorine, bromine and iodine which might be included in a revised version of the monograph. 


\title{
The Radiochemistry of Fluorine, Chlorine, Bromine and lodine
}

\author{
JACOB KTEINBERG AND G. A. COWAN \\ University of California \\ Ios Alamos Scientific Laboratory \\ Ios Alamos, New Mexico \\ January 1960
}

I. GENERAL RETHERENCES TO THE INORGANIC AND ANALYTICAL

CHEMISTRY OF THE HALOGENS

GmeIIn's Handbuch der anorganischen Chemie, System-Numer 8. Verlag Chemie, G.m.b.h., Berlin, 1933.

W. F. Hillebrend, G. E. F. Lundell, H. A. Bxight and J. I. Hoffman, Applied Inorganic Analysis, and Edition, John Wiley and Sons, Inc., New York, 1953, Ch. 47 and 48.

W. M. Latimer and J. H. HIldebrand, Reference Book of Inorganic

Chemistry, 3rd Edition, The Macmilian Company, 1951, Ch. X.

T. Moeller, Inorganic Chemistry, An Advanced Textbook, Jobn Wiley and Sons, Inc., New York, 1952, Ch. 13.

H. Remy, Treatise on Inorganic Chemistry (translated by J.S. Anderson), Elsevier Publishing Company, Amsterdam, 1956, Ch. 17.

N. V. Sidgwick, The Chemical Elements and Their Compounds, Oxford University Press, London, 1959, pp. 1097-1261.

F. P. Treadwell and W. T. Hall, Analytical Chemistry, 9th Edition, Vol. I, John Wiley and Sons, Inc., New York, 1937, pp. 299-323.

C. J. Rodden, Analytical Caemistry of the Manhattan Project, Chs. 5 and 7, McGraw Hill Book Co., New York, 1950. 
II. TABTLE OF ISOTOPES *F FLUORTIV, CHLORIVI, BROAINE AND IODINE

\begin{tabular}{|c|c|c|c|}
\hline Isotope & Half Life & Type of Decay & Method of Preparation \\
\hline \multirow[t]{4}{*}{$F^{27}$} & $\sim 70 \mathrm{sec}$ & $\beta^{+}$ & $\mathbb{N}^{24}(\alpha, n)$ \\
\hline & & & $0^{26}(\alpha, n)$ \\
\hline & & & $0^{26}(p, y)$ \\
\hline & & & $F^{19}(\gamma, 2 n)$ \\
\hline \multirow[t]{5}{*}{$F^{28}$} & $\sim 110 \mathrm{~min}$ & $\left\{\beta^{+} 97 \%\right.$ & $0^{28}(\alpha, p n)$ \\
\hline & & $\{\mathrm{EC} 3 \%$ & $0^{38}(p, n)$ \\
\hline & & & $F^{19}(n, 2 n)$ \\
\hline & & & $F^{29}(\gamma, n)$ \\
\hline & & & $\begin{array}{l}\mathrm{Ne}^{20}(\mathrm{~d}, \alpha) \\
\text { and others }\end{array}$ \\
\hline$F^{19}$ & stable ( & (abundance $100 \%$ ) & Natural \\
\hline \multirow[t]{3}{*}{$F^{20}$} & $10.7 \mathrm{sec}$ & $\beta^{-}$ & $F^{19}(\alpha, p)$ \\
\hline & & & $F^{19}(n, y)$ \\
\hline & & & $\mathrm{Na}^{23}(n, \alpha)$ \\
\hline \multirow[t]{2}{*}{$\mathrm{CI}^{32}$} & $-0.3 \mathrm{sec}$ & $B^{+}$ & $s^{32}(p, n)$ \\
\hline & & $\alpha-10^{-2} \phi$ & \\
\hline \multirow[t]{3}{*}{$\mathrm{Cl}^{33}$} & $-2.4 \mathrm{sec}$ & $\beta^{+}$ & $s^{32}(a, n)$ \\
\hline & & & $s^{33}(p, n)$ \\
\hline & & & $\mathrm{Cl}^{35}(\gamma, 2 \mathrm{n})$ \\
\hline \multirow[t]{2}{*}{$\mathrm{Cl}^{3 \mathrm{Am}}$} & $32.4 \mathrm{~min}$ & $\beta^{+} \sim 50 \%$ & $C 1^{35}(p, p n)$ \\
\hline & & $\{I T-50 \%$ & \\
\hline \multirow[t]{4}{*}{$\mathrm{Cl}^{34}$} & $\sim 1.5 \mathrm{sec}$ & $\beta^{+}$ & Deughter $\mathrm{CI}^{3 \mathrm{Am}}$ \\
\hline & & & $\mathrm{P}^{32}(\alpha, n)$ \\
\hline & & & $s^{33}(a, n)$ \\
\hline & & & and others \\
\hline $\mathrm{Cl}^{35}$ & atable & abundance $-75.5 \%)$ & Natural \\
\hline \multirow[t]{2}{*}{$\mathrm{Cl}^{36}$} & $4.4 \times 10^{5}$ yea & $\left\{B^{-} 98.3 \%\right.$ & $\mathrm{Cl}^{35}(n, y)$ \\
\hline & & $\operatorname{lEC}(K) 1.7 \%$ & $\mathrm{Cl}^{35}(\mathrm{~d}, \mathrm{p})$ \\
\hline $\mathrm{Cl}^{37}$ & stable (c & abundance $\sim 24.5 \%$ ) & Natural \\
\hline \multirow[t]{3}{*}{$\mathrm{Cl}^{38}$} & $\sim 37 \min$ & $B^{-}$ & $C l^{3 T}(\alpha, p)$ \\
\hline & & & $\mathrm{Cl}^{3 \mathrm{~T}}(\mathrm{n}, \gamma)$ \\
\hline & & & and others \\
\hline
\end{tabular}


II. TABLE OF ISOTOPES* OF FLUORCNE, CHLORLVE, BROMINE AND IODINE (Cont 'd)

\begin{tabular}{|c|c|c|c|}
\hline Isotope & Haif Iife & Type of Decay & Method of Preparation \\
\hline $\mathrm{CI}^{39}$ & $\sim 1 \mathrm{hr}$ & $B^{m}$ & $A^{40}(\gamma, p)$ \\
\hline $\mathrm{Cl}^{40}$ & $1.4 \min$ & $\beta^{-}$ & $\begin{array}{c}\text { Spall Fe, } \mathrm{Co}, \mathrm{Cu}, \mathrm{As} \\
\mathrm{A}^{40}(\mathrm{n}, \mathrm{p})\end{array}$ \\
\hline $\mathrm{Br}^{\mathrm{TA}}$ & $-40 \min$ & $\left\{\begin{array}{l}\beta^{+} \\
E C\end{array}\right.$ & $\mathrm{Cu}^{65}\left(\mathrm{c}^{12}, 3 \mathrm{n}\right)$ \\
\hline $\mathrm{Br}^{75}$ & $\sim 1.6 \mathrm{hr}$ & $\left\{\begin{array}{l}\beta^{+} \\
E C\end{array}\right.$ & $\begin{array}{l}\operatorname{Cu}^{65}\left(c^{12}, 2 n\right) \\
\operatorname{Se}^{74}(d, n) \\
\operatorname{Se}^{74}(p, \gamma)\end{array}$ \\
\hline$B x^{76}$ & $-17 \mathrm{hx}$ & $\beta^{+}$ & $\begin{array}{l}\operatorname{As}^{75}(\alpha, 3 n) \\
\operatorname{Se}^{78}(p, n)\end{array}$ \\
\hline $\mathrm{Br}{ }^{7}$ & $-57 \mathrm{hr}$ & $\begin{cases}\text { EC } 99 \% ; \beta^{+} 1 \% \\
\text { EC 95\%; } \beta^{+} 5 \%\end{cases}$ & $\begin{array}{l}\operatorname{As}^{75}(\alpha, 2 n) \\
\operatorname{Se}^{74}(\alpha, p) \\
\operatorname{Se}^{76}(\alpha, n)\end{array}$ \\
\hline $\mathrm{Br}^{72 m}$ & $6.4 \min$ & IT & $\begin{array}{l}\operatorname{As}^{75}(\alpha, n) \\
\operatorname{Se}^{77}(\alpha, n) \\
\operatorname{Se}^{78}(p, n) \\
\operatorname{Br}^{79}(\gamma, n) \\
\operatorname{Br}^{79}(n, 2 n)\end{array}$ \\
\hline $\mathrm{Br}^{78}$ & $<6 \min$ & $\beta^{+}$ & Daughter $\mathrm{Br} \mathrm{r}^{78 \mathrm{~m}}$ \\
\hline$B r^{79}$ & stable & (abundance $-50.5 \%$ ) & Natural \\
\hline $\mathrm{Br}^{80 \mathrm{~m}}$ & $-4.5 \mathrm{hr}$ & IT & $\begin{array}{l}\operatorname{Se}^{80}(d, 2 n) \\
\operatorname{Se}^{77}(\alpha, p) \\
\operatorname{Se}^{80}(p, n) \\
\operatorname{Br}^{79}(n, \gamma) \\
\text { and others }\end{array}$ \\
\hline $\mathrm{Br}^{80}$ & $\sim 18 \min$ & $\left\{\begin{array}{l}\beta^{-} 92 \% \\
\beta^{+} \sim 3 \% \\
E C \sim 5 \%\end{array}\right.$ & $\begin{array}{c}\mathrm{Se}^{80}(p, n) \\
\mathrm{Br}^{79}(n, \gamma) \\
\mathrm{Br} r^{72}(\mathrm{~d}, \mathrm{p}) \\
\mathrm{Br}^{81}(\gamma, n) \\
\text { Deughter } \mathrm{Br}{ }^{80 m} \\
\mathrm{~B} x^{81}(n, 2 n)\end{array}$ \\
\hline $\mathrm{Br}^{81}$ & stable & (abundance $\sim 49.5 \%$ ) & Natural \\
\hline
\end{tabular}


II. TABLE OF ISOTOPES* OF FLUORINE, CHLORINE, BROMINE AND IODINE (Cont' $d$ )

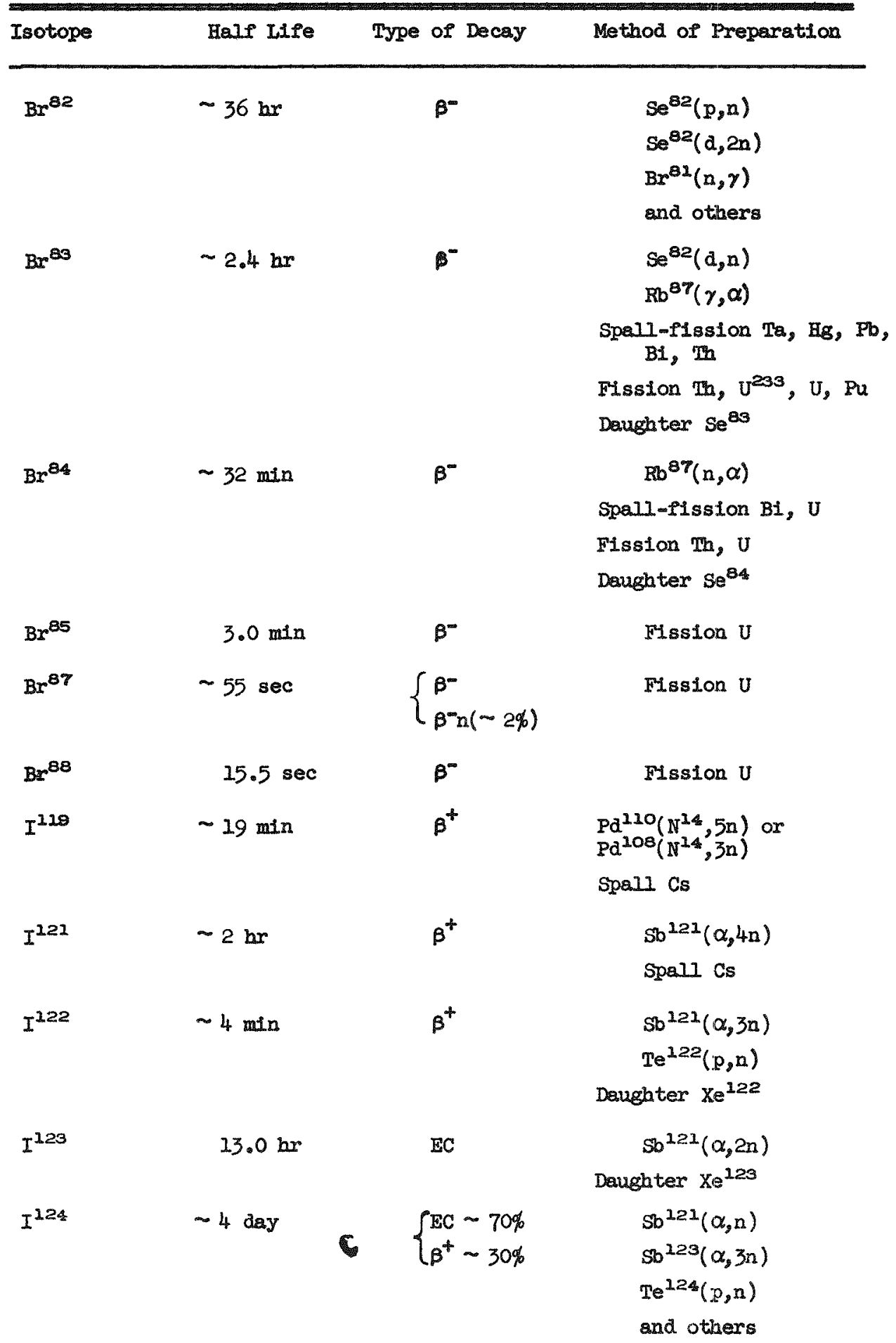


II. TABLE OF ISOTOPES* OF FLOORINE, CHLORINE, BROMITE AND IODINE (Cont'd)

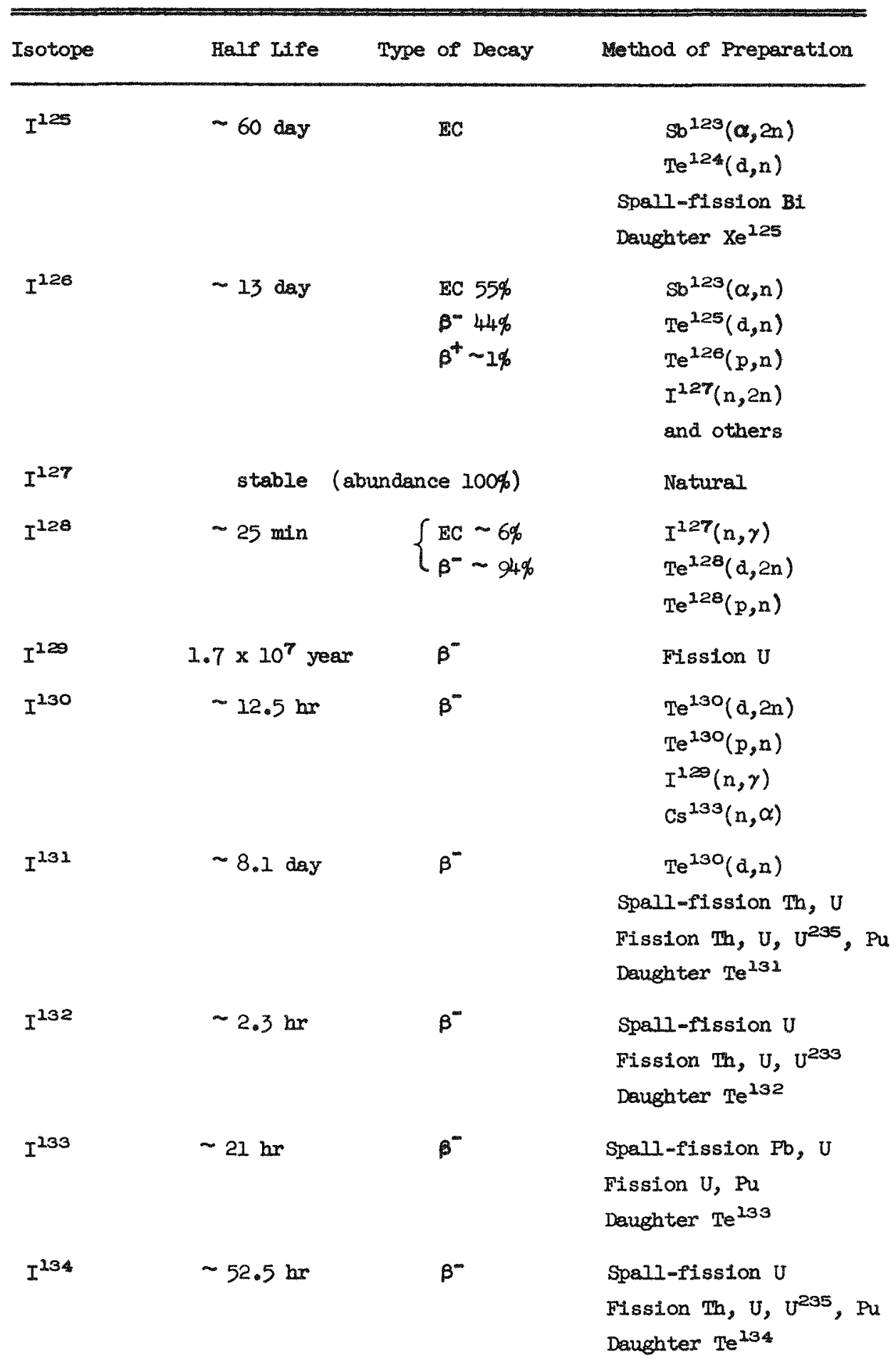


II. TABLIS OF ISOTOPES* OF FLUORINT, CHLORINE, BROMINE AND IODINE (Cont'd)

\begin{tabular}{|c|c|c|c|}
\hline Isotope & HaIf Life & Type of Decay & Method of Preparation \\
\hline$I^{135}$ & $\sim 6.7 \mathrm{hr}$ & $\beta^{-\infty}$ & $\begin{array}{l}\text { Spall-flssion U } \\
\text { Fission Th, U, Pu } \\
\text { Deughter } \mathrm{Te}^{135}\end{array}$ \\
\hline$I^{137}$ & $\sim 22 \sec$ & $\left\{\begin{array}{l}\beta^{-} \\
\beta^{-m} n(\sim 6 \%\end{array}\right.$ & Fission U, Pu \\
\hline$I^{138}$ & $5.9 \mathrm{sec}$ & $\beta^{-\infty}$ & Fission $U$, ancestor $\mathrm{Cs}^{138}$ \\
\hline$I^{139}$ & $2.7 \mathrm{sec}$ & $\beta^{-}$ & Fission $\mathrm{U}$, ancestor $\mathrm{Ba}^{139}$ \\
\hline
\end{tabular}

III. A REVIEW OF SOME ASPECTS OF HALOGEN CHEMTSIRY OF INTEREST TO RADIOCHEMTISIS

1. General Properties of the Halogens

Fluorine, chlorine, bromine, and lodine, with the respectlve atomic numbers 9, 17, 35 and 53, along with astatine, comprise the balogens. These elements possess an $\mathrm{s}^{2} \mathrm{p}^{5}$ valence shell configuration. Fluorine differs markedly in its chemistry from the other halogens. The difference observed are largely attributable to Its very high electronegativity, small size, and inability to comadion more than eight electrons in the valence shell.

The halogens exhibit a maxised tendency to attain inert gas configurations, 1.e., an $\underline{s}^{2} \underline{p}^{6}$ outer shell configuration. This is manifested in the diatomic nature of the elementary molecules, in the relatively large amounts of energy required to dissociate these molecules (heat of dissociation, kcal/mole: $F_{2} 38 \pm 3 ; \mathrm{Cl}_{2}$ 57.2; $\mathrm{Br}_{2}$ 45.4; $\left.I_{2}, 35.5\right)$, and in the large values for the electron affinities of the atoms $(F, 83 \pm 3 ; \mathrm{Cl}, 86.5 ; \mathrm{Br}$, 81.5; I, $74.2 \mathrm{kcal} / \mathrm{g}$ atom).

The great tendency for the halogens to reach octet configurations is reflected in the abundance of hallde salts and in the large number of comm pounds in which the elements show a covalence of one. For fluorine, this is the only covalence permitted; for the other halogens, where the valence 
shell can hold more than eight electrons, covelences greater than ane are not uncamon. Examples in which chlorine, bromine, and lodine have more than elght electrons in the valence shell are to be found among the interbalogens, where such compounds as $\mathrm{ClF}_{3}, \mathrm{BrF}_{5}$, and IF 1zed. Thus in chlorine trifluoride there are ten electrons around the central chlorine atcm, three pairs shared with Pluorine atams and two unshared pairs. As would be expected, lodine, the largest of the halogens, can form the greatest number of covalent bonds.

In their compounds with metals the balogens are necessarily in a negative one oxidation state. With active metals which give rise to large cations of low charge, i.g., sodium, calcium, this oxddation state is an ionic one. On the other hand, with metals, even active ones such as beryllium and aluminum, which are potential sources of lons of relatively high charge density, the bonds between halogen, particularly chlorine, bromine or iodine, and metal are frequently covalent in character. With a metal exhibiting a variety of oxidation states, the covalent character of any one halide type increases with increasing oxidation state of the metal. This trend is generally accompanied by increasing volatility as well as increasing solubility in non-polar organic solvents (e.g., compare $\mathrm{FeCl}_{2}$ and $\mathrm{FeCl}_{3}$ ).

In union with other non-metals, fluorine, the most electronegative element known, invariably may be regarded as being in a negatlve oxidation state. The other halogens may be considered as exhibiting either electronegative or electropositive character depending upon the electronegativity of the element to which they are joined. The most common situations in which chlorine, bromine, and iodine exhibit positive oxidation states are to be found in the interhalogens and in the various oxyhalogen compounds. Positive oxidation states of $1,3,5$, and 7 are known. It should be emphasized that in these positive oxidation states the halogens are joined to the more electronegatfve element by essentially covalent bonds.

It is noteworthy that lodine, the least electronegative halogen, is actually capable of forming the cationic species $I^{+}$. This extremely unstable entity can be considerably stablized by coordination with such organic bases as pyridine. Thus such compounds as [I $\mathrm{py}_{2}$ ] $\mathrm{NO}_{3}$ and [I py. $\mathrm{ClO}_{4}$, among others, have been prepared.

Inasmuch as changes in oxidation state are frequently of significance in radiochemical procedures for the analysis of chlorine, bronine and iodine, the potential relationships which exist among the various oxidation states of these elements are shown on page 8. 
Acialc Solutions:

$$
\mathrm{Cl}^{-} \stackrel{-1.36}{\longrightarrow} \mathrm{Cl}_{2} \stackrel{-1.62}{\longrightarrow} \mathrm{HC10} \stackrel{-1.63}{-1.47} \mathrm{HCIO}_{2} \stackrel{-1.21}{\longrightarrow} \mathrm{C1O}_{3}^{--1.19} \stackrel{-19}{\longrightarrow} \mathrm{ClO}_{4}^{-}
$$
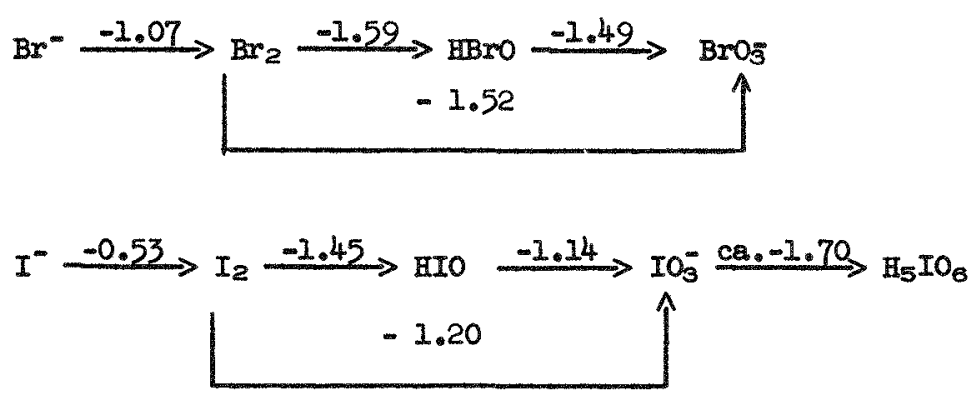

Basic Solutions:

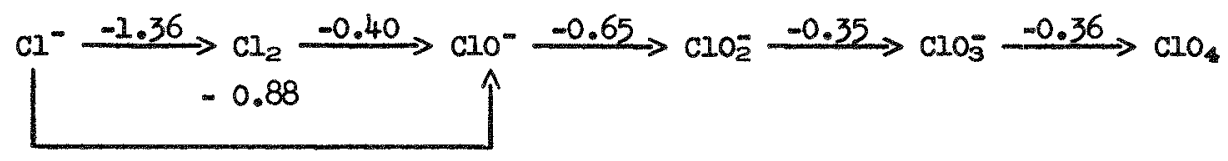

$$
\begin{aligned}
& \mathrm{Br}^{-} \stackrel{-1.07}{\longrightarrow} \mathrm{Br}_{2} \stackrel{-0.45}{\longrightarrow} \mathrm{BrO}^{-} \stackrel{-0.54}{\longrightarrow} \mathrm{BrO}_{3}^{-} \\
& -0.49 \\
& \mathrm{I}^{-} \stackrel{-0.53}{\longrightarrow} \mathrm{I}_{2} \stackrel{-0.45}{\longrightarrow} \mathrm{IO}^{-} \stackrel{-0.14}{\longrightarrow} \mathrm{IO}_{3}^{-} \stackrel{\mathrm{C8} .}{\stackrel{-0.7}{\longrightarrow}} \mathrm{H}_{3} \mathrm{IO}_{6} \\
& -0.49 \quad \hat{\jmath}
\end{aligned}
$$


In view of the fact that the formation of elementary bromine and lodine is of importance in a number of methods for the anslytical determination of these elements, some properties of these substances are described. As is evident from the potential data cited above, both bromine and lodine are fairly strong oxldizing agents. Bromine is rather soluble in water, $3.55 \mathrm{~g}$ dissolving in $100 \mathrm{~g}$ of water at $20^{\circ}$; the solubility of lodine is much smaller $\left(0.34 \mathrm{~g}\right.$ per liter of solution at $\left.25^{\circ}\right)$. For both elements, solution in water is accompanied by the main reaction

$$
\mathrm{X}_{2}+\mathrm{H}_{2} \mathrm{O}=\mathrm{H}^{+}+\mathrm{X}^{-}+\mathrm{HXO} \text {. }
$$

For bromine, the equilibrium constant for this reaction is $5 \times 10^{-9}$; for iodine, $3 \times 10^{-13}$. (For chlorine, the constant is $4 \times 10^{-4}$. The rem action is of no significance for fluorine, which vigorously liberates oxygen and ozone from liquid water with the formation of hydrofluoric acid.) In cold dilute alkaline solutions hypohalite salts are formed; in warm concentrated alkaline solutions the hypobalite lon disproportion. ates to halate $\left(\mathrm{XO}_{3}^{-}\right)$and halide lons.

Bromine is completely miscible with comon organic solvents. Iodine is generally appreciably soluble in organic solvents. In solvents exbibiting no donor characteristics, e.8., carbon disulfide, chloroform, carbon tetrachloride, the solutions are violet in color. In aromatic solvents such as benzene and toluene the solutions are red. In solvents which may be regarded as typlcal Iewis bases (e.g., ether, pyridine), lodine is most soluble and gives brown solutions. There is little doubt that in both the red and brown solutions solvation of the lodine occurs.

An important characteristic of elementary iodine is its ability to combine with iodide Ion to form polyiodide anjons, $I_{n}^{-}$, of which the triiodide ion, $I_{3}^{-}$, is the most stable. Other polyiodide ions which have been identified are $I_{5}^{-}, I_{7}^{-}$and $I_{9}^{\infty}$. The most stable polylodide salts are formed with large cations, e.g., $\mathrm{Cs}^{+}$, quaternary amonium ions. Tribromides are known, but they are mach less stable than trilodides. The existence of the trichloride ion in solution has been definitely established, but no stable solid salts of this anion have been isolated. The trifluoride ion is unknown. The trend in stability of the tringlide ions in aqueous solum tion is shown by the values for the equilibrium constants for the reaction.

$$
\mathrm{X}_{2}+\mathrm{X}^{-}=\mathrm{X}_{3}-
$$

For lodine the constant at $25^{\circ}$ is 725 ; for bromine 17.8 ; and for chlorine $10^{-2}$. 
Most of the analytical determinations for the halogens involve precipitation reactions of the halide lons. Fluarine may be preclpitated as the calcium salt $\left(\mathrm{K}_{\mathrm{gp}} 18^{\circ}: 3.4 \times 10^{-12}\right)$ or as lead chloropluoride $\mathrm{PbF}_{2} \cdot \mathrm{PbCl}_{2}$ ). Precipitation of the calcium ault is not entirely satisfactary even when the solution to be tested contains appreclable amounts of fluoride, low results camonly being obtained. Precipltation of lead chlorofluoride is usualiy carried out in the $\mathrm{pH}$ range $3.6-5.6$; the precipitate can be welghed as such, or the fluroine content can be determined indirectly from titration of the chloride.

Caloride, bromide, or iodide can be determined by precipttation with silver Ion $\left(\mathrm{K}_{\mathrm{sp}} 25^{\circ}\right.$ : AgCl $1.56 \times 10^{-10} ; \mathrm{AgBr} 7.7 \times 10^{-13} ; \mathrm{AgI} 1.5 \times 10^{-16}$. Sflver fluoride exhibits a solubility of $181.5 \mathrm{~g}$ per $100 \mathrm{~g}$ of water at about $20^{\circ}$.) The analytical procedure may be a gravimetric one or a titration. Iodide may be preclpitated and determined as the palladiun(II) salt. As a matter of fact, precipitation by means of palladiun(II) chloride from a slightly acidic solution is a satisfactory method for the separation of lodide from chloride and bromide. A more comon way of seperating lodide from solution with the other balldes is by the addition of nitrous acid, which converts lodide to free lodine and is without effect on the ramalning balldes. Separation of bromide from chloride can be accauplished by oxidation of the formex to elementary bromine by potassium permanganate in acetic acld solution. It can also be affected. from the silver salts; silver bromide is essentlajly insoluble in an aqueous solution of amonium carbonate, whereas the chloride is soluble.

\section{Ion Exchange Separations}

Ion exchange has been used Infrequently for separation of the balogens from each other, probably because the well known conversion to the free element followed by extraction into an organic solvent is so well estabIished.

An Ion exchange separation of the halide lons was demonstrated early in the history of modern exchange terlals. I The amonium salts of fluoride, chloride, browide, and lodide were absorbed on Dowex-2 (100200 mesh) in the nitrate form. Elution was performed at rocm temperature with IM sodium nitrate at a $\mathrm{pH}$ of 10.4. Fluoride comes off first. Peak to valley ratios of 100 to 600 between $\mathrm{F}^{-}, \mathrm{Cl}^{-}, \mathrm{Br}^{-}$, and $\mathrm{I}^{-}$were obtained Indicating good separation.

A similar separation has been used for determining $\mathrm{Cl}$ and $\mathrm{Br}$ in mixtures of the two by absorption ${ }^{2}$ on a strong base anion resin, XE 67 supplied by Rohm and Hass Company. The eluting agent was $0.6 \mathrm{M} \mathrm{NaNO}_{3}$ containing a nonionic wetting agent. A further application of this method has been 
used for the analytical separation of $\mathrm{Cl}, \mathrm{Br}$, and I on Dowex $1-\mathrm{XIO}$ resin, ${ }^{3}$ the eluting agent was $0.5 \mathrm{M} \mathrm{NaNO}_{3}$. Another halide separation on a strong base resin used $0.5 \mathrm{M} \mathrm{NaNO}_{3}$ to elute $\mathrm{Cl}$. The eluant concentration was then increased to $2 M$ to accelerate the elution of $\mathrm{Br}^{-}$and $\mathrm{I}^{-4}$. $^{-}$

A method for separating $\mathrm{Cl}^{-}, \mathrm{Br}^{-}$and $\mathrm{I}^{-}$makes use of precipitation chromstography. ${ }^{5} \mathrm{~A}$ colurn is made of $\mathrm{AgNO}_{3}$ or $\mathrm{Ag}_{2} \mathrm{SO}_{4}$ and alumina in a 1 to 9 ratio of precipitant to filler. The mixture of ions is passed through the columns and developed in gunlight for 5 to 15 minutes. The limit of identification is $8 \mathrm{y}$ for $\mathrm{I}^{-}$and 14 to $15 \mathrm{y}$ for $\mathrm{Br}^{-}$and $\mathrm{Cl}^{-}$. The halides have been separated on paper impregnated with $\mathrm{Ag}_{2} \mathrm{CrO}_{4} \cdot 6$ Paper chromatography and activation analysis have been combined for the determination of $\mathrm{S}, \mathrm{Br}$, and $\mathrm{Cl}$ in organic compounds.7

Fluoride has been quantitatively separated from 500 times as mach phosphorus on a Dowex 1-X10 column in the hydroxide form. ${ }^{8}$ The 100-200 mesh, strong base resin was eycled three times with $3 \mathrm{~N} \mathrm{NaOH}$ and $3 \mathrm{~N}$ HCI, then left in the hydroxide form. The elution was performed with $0.5 \mathrm{~N}$ $\mathrm{NaOH}$.

F'luoride has been separated from aluminum by eluting from the alkaline form of a strong base resin. ${ }^{9}$ The aluminum comes off the column first.

Rates of uptake and an afrinity serfes for several anions including the halides have been determined for hydrous zirconium oxide. 10 The affinity series determined with $0.1 \mathrm{~N}$ solutions is: $\mathrm{Cl}^{-}, \mathrm{NO}_{3}^{-}>\mathrm{Br}^{-}, \mathrm{I}^{-}$, $\mathrm{CrO}_{4}^{=} \gg \mathrm{SO}_{4}^{=}$.

A synthetic inorganic ion exchanger was used to remove large quantities of unwanted $F^{18}$ activity that formed as a by-product in a cyclotron irradiation. 11 The solution in concentrated HCl was passed through an $\mathrm{Al}_{2} \mathrm{O}_{3}$ column and more than $90 \%$ of the fluoride was absorbed.

\section{Solvent Extraction Separations}

Extraction of the free element form of the halogen into an organic solvent $\left(\mathrm{CCl}_{4}, \mathrm{CHCl}_{3}\right)$ after use of the proper oxidjzing agent has long been a favored separation method for $\mathrm{Cl}, \mathrm{Br}$, and $\mathrm{I}$. Several detailed examples are given in the section on procedures.

Because many organic compounds of the halogens can be prepared, Szilard-Chalmers extraction systems have been very commonly used to increase the specific activity of a halogen. ${ }^{12}$ The recoil energy of the incident nuclear particle breaks the bond between the halogen and the carbon atom. Extraction of the organic solution with water then yields a high specific activity of the halide.

Neutron activation followed by extraction of $B r$ and I and the dis- 
tillation of $\mathrm{Cl}$ has been used as an analytical method to determine trace amounts of mixed balides. 13

Tetraphenyl stibonium sulfate bas been used to extract fluoride from a solution in 97-98\% yield ${ }^{14}$ The method is more useful for concentration purposes than as a highly specific separation. A few drops of $\mathrm{H}_{2} \mathrm{SO}_{4}$ are added to the solution containing up to $5 \mathrm{mg}$ of $\mathrm{F}^{*} \cdot 0.125$ millimole of tetraphenyl stibonium sulfate is added and the volume brought to $19 \mathrm{mil}$. It is shaken with three successive $5 \mathrm{ml}$ portions of $\mathrm{CCl}_{4}$ and the organic layer is evaporated and weighed.

\section{Distillation Separations}

Distillation of fluorine as hydrofluosilicic acid is comonly used for separating fluoride from interfering ions before a titration or precipitation. $15,16,17$

Chlorine, bromine, and iodine can be separated by selective oxidation and distillation of the element. Iodine is oxddized by adatition of $\mathrm{NaNO}_{2}$ in dilute $\mathrm{H}_{2} \mathrm{SO}_{4}{ }^{20}$ Bromine can be oxidized with telluric acid, ${ }^{19}$ $\mathrm{KMO}_{4}$ in acetic acid, or $\mathrm{KH}\left(\mathrm{IO}_{3}\right)_{2}$ in dilute nitric acid. Chlorine can be oxidized by addition of concentrated $\mathrm{BNO}_{3}$.

\section{Exchange Reactions}

A prime requisite in radiochemical analytical procedures is the complete exchange between the radioactive species being determined and carrier. Observations on exchange between various hologen entities in aqueous medium are sumarized below.

Exchange between free halogen and halide ion in solution is complete within the minimum time of mixing and separation. Taree plausible mechanisms for exchange have been postulated. ${ }^{20}$ These involve the equilibria shown below:

$$
\begin{array}{ll}
\text { (1) } \mathrm{X}_{2}+\mathrm{X}^{*_{-}}=\mathrm{X}_{3}^{*-}(\mathrm{X}=\mathrm{Cl}, \mathrm{Br}, \mathrm{I}) & \mathrm{K}_{1}=10^{-2} \\
\text { (2) } \mathrm{X}_{2}+\mathrm{OH}^{-}=\mathrm{HXO}+\mathrm{X}^{-} & \mathrm{K}_{2}=4 \times 10^{10} \\
\text { (3) } \mathrm{X}_{2}+\mathrm{H}_{2} \mathrm{O}=\mathrm{HXO}+\mathrm{H}^{+}+\mathrm{X}^{-} & \mathrm{K}_{3}=4 \times 10^{-4}
\end{array}
$$

In view of the high exchange velocity it is extremely difficult to dis tinguish between these three nechanisms. However, there is strong evidence 21 that exchange occurs by mechanism (I), that is, through trihalide ion formation.

Tracer aqueous bromine exchanges rapidly with freshly precipitated silver bromide. 22

Exchange between elementary chlorine and chlorate ion in acidic 
solution both at room temperature and elevated temperatures is extremely slow. Neither elementary chlorine nor chloride ion exchange with perchloric ion either in alkaline or acidic solution. 24 Exchange of chlorine activity between hypochlorite and chlorlte lons in basic solution is very slow. 23 Exchange between chlorate ion and perchlorate ion does not occur at room terperature, or even at $90^{\circ}$, in neutral, basic or acidic solution. 25

The rate of excbange between freshly formed silver broutde and aqueous bromide Ion is very rapid, homogeneous distribution of activity being attained within a few seconds. ${ }^{26}$ It has been reported that the rate of exchange between bromine and bromate ion in acidic aqueous solution is given by the expression

$$
\mathrm{R}=\mathrm{k}\left[\mathrm{Br} \mathrm{r}_{2}\right]^{\mathrm{m}}\left[\mathrm{BrO}_{3}^{-}\right]^{\mathrm{n}}\left[\mathrm{H}^{+}\right]^{\mathrm{p}}
$$

where $\mathrm{k}=0.023 \mathrm{~mole} \mathrm{e}^{-2.1} \mathrm{I}_{0}{ }^{2.1} \mathrm{hr}^{-1}, \mathrm{~m}=0.3 \pm 0.05, \mathrm{n}=1.7 \pm 0.05$, and $p=1.1 \pm 0.05$. It is proposed that the following set of reactions is applicable to the system:

$$
\begin{aligned}
& \mathrm{HBr}+\mathrm{HBrO}_{3}=\mathrm{HBrO}_{2}+\mathrm{HBrO} \\
& \mathrm{HBr}+\mathrm{HBrO}_{2}=2 \mathrm{HBrO} \\
& \mathrm{HBrO}+\mathrm{HBr}=\mathrm{Br}_{2}+\mathrm{H}_{2} \mathrm{O}
\end{aligned}
$$

In the radiochemical determination of bromine activities in fission products, rapid exchange can be ensured by the addition of bromate carrier to the sample and its reduction to bromide ion. 28

The exchange in acidic solution of elementary lodine with lodate or periodate ( $\mathrm{IO}_{4}^{-}$) ion, and of lodate with perlodate in acidic or alkaline solution is slow. 29,30 The experimentally observed ${ }^{31}$ rate law for the iodine-iodate exchange reaction has been determined to be

$$
\mathrm{R}=\left(\mathrm{I}_{2}\right)^{0.6}\left(\mathrm{H}^{+}\right)^{1.8}\left(\mathrm{IO}_{3}^{-}\right)^{0.8}\left[\mathrm{k}\left(\mathrm{IO}_{3}^{-}\right)+\mathrm{k}^{\prime}\left(\mathrm{X}^{-}\right)\right] \mathrm{r}
$$

In which $X^{-}$may be perchlorate, nitrate or sulfate ion, and $I$ is the appropriate function of the activity coefficients of the reactants and transition states. At $25^{\circ}, \mathrm{k}$ has the value $7.40 \pm 0.251 .3 .2$ mole -3.2

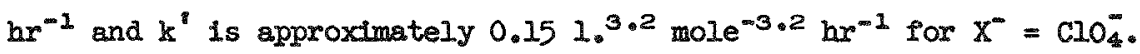
The activation energy is about $20 \mathrm{kcal}$. mole $\mathrm{e}^{-1}$. The exchange reaction has been shown to occur by the same mechanism as the iodide-Lodate reaction; the rate law for the latter reaction at low jodide lon concentration is given by the expression

$$
-\alpha\left(I O_{3}^{-}\right) / \partial t=\left(I^{-}\right)\left(I O_{3}^{\infty}\right)\left(\mathrm{H}^{+}\right)^{3}\left[k_{6}\left(I O_{3}^{\infty}\right)+k_{6}^{8}\left(X^{\infty}\right)\right] \mathrm{r}
$$

where at $25^{\circ} \mathrm{k}_{6}$ is $(5.7 \pm 1.3) \times 10^{6} 1 .^{5}$ mole $\mathrm{e}^{-5} \mathrm{sec}^{-1}$, and $\mathrm{k}_{6}^{\prime}$ for $\mathrm{x}^{-}=$ 
$\mathrm{ClO}_{4}^{-}$is about $1.1 \times 10^{5} 10^{5} \mathrm{~mole}^{-5} \mathrm{sec}^{-1}$. Studies ${ }^{32}$ of the lodine-Lodate exchange reaction in solutions of constant lonic strength and having bigh $\left(\mathrm{ClO}_{4}^{-}\right) /\left(\mathrm{IO}_{3}^{-}\right)$ratios give the following rate law:

$$
\mathrm{R}=\mathrm{k}\left(\mathrm{I}^{-}\right)\left(\mathrm{IO}_{3}^{-}\right)\left(\mathrm{H}^{+}\right)^{3}
$$

This is entirely consistent with the previous rate expression noted immediately above.

In radiochentical analyses for lodine, complete exchange of radiolodine with carriex presumably can be obtained by the addition of the latter as lodide Ion and subsequent oxidation to periodste, e.g., by hypochlorite ion in basic solution, followed by reduction to lodide by means of bisulfite in acidic solution. 33

IV. COLLECTION OF RADTOCHEMTCAL PROCEDURES FOR FLUORINE, CHLORTNE, BRONTINE, AND IODINE

PROCEDURE I - FLUORTNE

Source - A. Turkevich, unpublished Ios Alamos work in 1955

Experimental work on a radiochemical procedure for fluorine which would provide a very high decontamination factor from flssion products, notably bromine and lodine, was begun by Turkevich in 1955. The procecure was not completely developed but is presented here as atarting point for a modifled procedure.

1. The sample was contained on 2 of organic fiber filter paper. It was brought into a soluble form by fusion in a Pt cruclble with 22 ms of anhydrous $\mathrm{K}_{2} \mathrm{CO}_{3}$ to which $5 \mathrm{ml}$ of carrier had been added (2.642 gms $\mathrm{KF} \cdot 2 \mathrm{H}_{2} \mathrm{O}$ in $100 \mathrm{ml}$ of $\mathrm{H}_{2} \mathrm{O}$ ). The covered Pt crucible was gradually in serted into a $500^{\circ} \mathrm{C}$ oven. After $30 \mathrm{~min}$ at $500^{\circ} \mathrm{C}$, the mass was charred black. It was then placed in an oven at $850^{\circ} \mathrm{C}$ and the carbonate was completely fused for several minutes. The cooled melt was dissolved in hot water.

2. The water solution was neutrallzed in the presence of brouphenol blue with 6N $\mathrm{HNO}_{3}$. The solution must not be permitted to become acidic but should remain slightly basic.

The pH was then adjusted with NaOH to a faint blue indicator color, then $2 \mathrm{ml}$ of $6 \mathrm{~N} \mathrm{HCl}, 5 \mathrm{gm}$ of $\mathrm{Pb}\left(\mathrm{NO}_{3}\right)_{2}$ in solution, and $5 \mathrm{gm}$ of sodium acetate in solution were added; the mixture then was stirred and digested. for one-half hour to precipitate PbClF.

3. The precipitate of PbCJF was dissolved in $20 \mathrm{ml}$ hot water containing a few drops of conc $\mathrm{HNO}_{3}$. $\mathrm{AgNO}_{3}$ was then added in sllight excess. 
The preclpitate of AgCI was centrifuged off and to the supernate a slight excess of HCI was added to precipltate excess silver. The AgCl was again centrifuged off.

4. The solution was again neutrallzed with NaOH to a faint blue color of bromphenol blue indicator, and $2 \mathrm{ml}$ of $6 \mathrm{~N} \mathrm{HCl}, 5$ of $\mathrm{Pb}\left(\mathrm{NO}_{3}\right)_{2}$ and 5 gm of sodium acetate were added. The precipitate was digested, centrifuged, and washed with cold water.

4. The PbClF precipitate was dissolved in hot water containing a few drops of $\mathrm{HNO}_{3}$. It was transferred to a distillation Plask with one gon of crushed Pyrex glass. $30 \mathrm{ml}$ of $70 \% \mathrm{HCIO}_{4}$ was added. Stean was passed In and the flask temperature held at $135^{\circ}-150^{\circ} \mathrm{C}$. A $50 \mathrm{ml}$ of distillate was collected in $45 \mathrm{~min}$ in flask containing, initially, $30 \mathrm{ml}$ of water plus a dozen NaOH pellets.

5. The distillate was neutralized with $\mathrm{HNO}_{3}$, excess $\mathrm{La}^{+3}$ added, and $\mathrm{LaF}_{3}$ precipitated. The yield from the above procedure was very small and wos not determined. (Note 1 ).

\section{Notes}

1. It was suggested that the first step after fusion should be the distillation of $\mathrm{H}_{2} \mathrm{SLF}_{6}$. This should then be followed by $\mathrm{PbClF}$ and AgCl scavenging steps and a second distillation of $\mathrm{H}_{2} \mathrm{SiF}_{6}$. Finally the fluorine should be precipitated as PbClF, in which form it would be weighed and counted.

PROCEDDURE 2 - CHLORINE

Source - W. W. Meinke, report AECD-2738, pp. 22. Aug. 1949

Element separated: Chlorine

Target material: Copper

Type of bbdt: All -

Yield: $60 \%$
Degree of purification: $10^{3}$

Procecure by: Batzel

Time for sep'n: 30 minutes

Equipment required: standard.

Procedure:

(1) Dissolve the copper in concentrated $\mathrm{HWO}_{3}$ containing 5 mg of chlorine carrier ( $1-2 \mathrm{ml}$ concentrated $\mathrm{HNO}_{3}$ for $0.1-0.3$ grams copper foil).

(2) Distill the chlorine into a centrifuge tube containing 2 ce of water, 2-3 drops of concentrated $\mathrm{HNO}_{3}$, and sufficient $\mathrm{AgNO}_{3}$ to precipitate the chlorine as AgCl. 
(3) Heat aimost to bolling, centrifuge the precipitate and wash with $3 \mathrm{cc}$ of $2 \mathrm{~N} \mathrm{ENO}_{3}$.

(4) Dissolve the $\mathrm{AgCl}$ in $3 \mathrm{cc}$ of $5 \mathrm{~N} \mathrm{NH}$ back carriers from standard $10 \mathrm{mg} / \mathrm{ml}$ solns, for $\mathrm{Cu}, \mathrm{Nl}, \mathrm{CO}, \mathrm{Zn}$, Fe (add as nitrates or sulfates) and then add 2 drops of $0.5 \mathrm{~N} K I$.

(5) Centrifuge and wash the precipitate with $2 \mathrm{cc}$ of $5 \mathrm{NI} \mathrm{NH}_{4} \mathrm{OH}$. Add the wash to the supernate and add excess $\mathrm{AgNO}_{3}$ to precipitate the excess lodide ( 5 drops of $0.5 \mathrm{~N} \mathrm{AgNO}_{3}$ ).

(6) Centrifuge and wash as before saving the supermate and wash.

(7) Make acid with $\mathrm{HHO}_{3}$ to preclpitate the $\mathrm{AgCl}$, centrifuge, and wash the precipitate twice with $3 \mathrm{ml}$ portions of $2 \mathrm{~N} \mathrm{ENO}_{3}$. The precipitate can be plated directly or dissolved in NE, OB and an aliquot taiken.

Remarks: If an appreciable amount of copper is to be dissolved the heat of reaction may drive the chlorine carrier into the recelving vessel before the copper is completely dissolved. If this occurs add $2.5 \mathrm{mg}$ of chlorine carrier as chloride to the weter in the recelver and after the copper is in solution add an aditional $2.5 \mathrm{mg}$ to the copper solution and distil as stated above. In case bromine is present it may be removed by making the solution $0.5 \mathrm{M}$ in $\mathrm{HNO}_{3}$ before precipitation, adaing $5 \mathrm{mg}$ of $\mathrm{Bx}^{-}$ carrier, 0.25 grams of amonium persulfate and bolling, thus oxidizing the $\mathrm{Br}^{-}$to $\mathrm{Br}_{2}$ and volatilizing. The solution should then be reduced with hydrazine and the chlorine precipitated as AgCl.

\section{PROCEDURE 3 - CHLORINE}

Source - W. H. Burgus, report IAA-1721, 2nd Ed., C1-1, Aug. 1958

\section{Introduction}

In the determination of chlorine in the presence of fission products, considerable decontamination is achieved by ferric hydroxide scavenging and by precipitation of silver lodide from ammoniacal medium. Precipitation of silver chloride in the presence of Versene* is then employed, primarily to remove chlorine from alkaline earth metal ions, but aiso to separate this element from many other activities. After additional decontamination, silver chloride is formed and the chlorine removed as

\footnotetext{
*Versene (Bersworth Chemical $C_{0}$ ) is the disodium salt of ethylenediaminetetracetic actd. Versene forms very stable soluble chelates with a large number of metallic ions.
} 
hydrogen chloride by treatment with concentrated sulfuric scid. Chiorine is finally precipitated as the mercury (I) compound, in which form it is counted. The chemical yleld is about $75 \%$ and a single analysis can be performed in two and one-half hours.

\section{Reagents}

$\mathrm{Cl}^{-}$ion carrier: $10 \mathrm{~ms} \mathrm{Cl}^{-} / \mathrm{ml}$. ( $\mathrm{HaCl}$ used as primary standard)

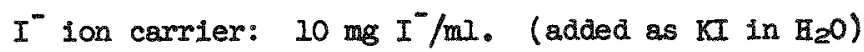

Fe carrier: $10 \mathrm{mg} \mathrm{Fe} / \mathrm{ml}$. (added as $\mathrm{Fe}\left(\mathrm{NO}_{3}\right)_{3} \cdot 6 \mathrm{H}_{2} \mathrm{O}$ in very dilute $\mathrm{BNO}_{3}$ )

$\mathrm{HNO}_{3}$ : conc.

HCHO: $37 \%$ aqueous solution

$\mathrm{NH}_{4} \mathrm{OH}$ : conc.

KOH: IOM

$\mathrm{AgNO}_{3}: 0.2 \mathrm{M}$

$\mathrm{Hg}_{2}\left(\mathrm{NO}_{3}\right)_{2}: 0.1 \mathrm{M}$ solution in dilute $\mathrm{HNO}_{3}$.

$\mathrm{KNO}_{2}$ : solid

Versene: disodium salt (analytical reagent grade, Bersworth Chemical Co.) $-8 \%$ aqueous solution.

$\mathrm{CCl}_{4}$

$\mathrm{C}_{2} \mathrm{H}_{5} \mathrm{OH}:$ absolute

\section{Equipment}

Centrifuge

Drying Oven

Block for holding centrifuge tubes

Forceps

Mounting Plates

Pipets: assorted sizes

Wash bottle

$2^{18}, 60^{\circ}$ funnels (two per sample)

Ground-off Hirsch funnels: Coors 000A (one per sample)

Filter chimeys (one per sample)

Filter flasks

125-ml separatory funnels (one per sample)

50-mi beakers (one per sample)

40-ml conical centrifuge tubes: Pyrex 8130 (seven per sample)

No. 40 Whatman filter paper $(9 \mathrm{~cm})$

No. 42 whatman iliter circles: $7 / 8^{\prime \prime}$ diameter-weighed

Stirring rods

Special still (see alagram next page) 
PROCHeures 3 (Cont'd)

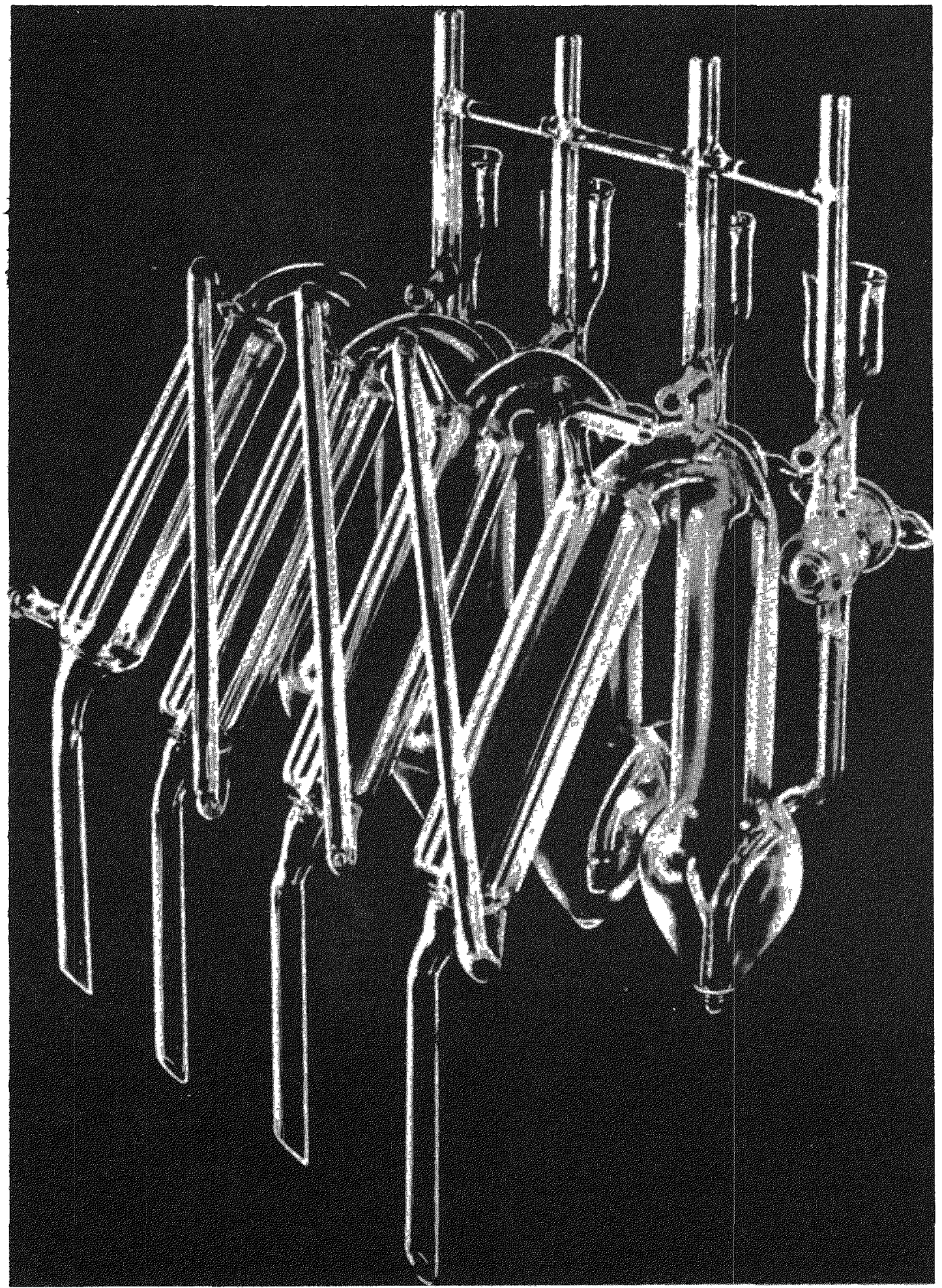


Step 1. To the solution containing radioactive chlorine and flasion products in a 40-ml conical centrifuge tube, add $1.00 \mathrm{ml}$ of standard NaCl carriex. Then add 4-6 drops of $\mathrm{Fe}$ carrier and precipitate $\mathrm{Fe}(\mathrm{OH})_{3}$ by the addition of a slight excess of conc. NH. $\mathrm{OH}$. Centrifuge, transfer the supernate containing $\mathrm{CI}^{-}$ion to a clean centrifuge tube, and discard the precipitate (Note 1 ).

Step 2. To the supernate add $5 \mathrm{ml}$ of conc. $\mathrm{NH}_{4} \mathrm{OH}$ and 4 drops of KI carrier solution. Precipitate AgI by the addition of a slight excess of $0.1 \mathrm{M} \mathrm{AgNO}_{3}$ solution. Coogulate the precipitate by beating, centriruge, transfer the supernate to a clean centrifuge tube, and discard the precipitate.

Step 3. To the supernate again add 4 drops of $\mathrm{KI}$ carrier and remove a AgI by-product preclpitate as in the previous step. However, this time filter the supernate through No. 40 Whatman filter paper $(9 \mathrm{~cm})$ in a 2 , $60^{\circ}$ funnel to ensure complete removal of AgI.

step 4. To the filtrate add $5 \mathrm{mz}$ of $8 \%$ versene solution and slowly acidify with conc. $\mathrm{HNO}_{3}$ to precipitate AgCl. Boil to coagulate the precipitate, centrifuge, and wash the $\mathrm{AgCl}$ with $30-40 \mathrm{ml}$ of $\mathrm{H}_{2} \mathrm{O}$ containing 2 drops of conc. $\mathrm{HNO}_{3}$. Discard the supernate and washings.

Step 5. Dissolve the AgCl precipitate in $3 \mathrm{ml}$ of conc. $\mathrm{NH}_{4} \mathrm{OH}$, add $5 \mathrm{ml}$ of an $8 \%$ Versene solution, dilute to $30 \mathrm{ml}$, and reprecipitate $\mathrm{AgCl}$ by the addition of conc. $\mathrm{HNO}_{3}$. Boil to coagulate the $\mathrm{AgCl}$ and wash as in the previous step.

Step 6. Dissolve the AgCl in 40 drops of conc. $\mathrm{NH}_{4} \mathrm{OH}$, add $15 \mathrm{ml}$ of $\mathrm{H}_{2} \mathrm{O}, 10$ drops of $10 \mathrm{M} \mathrm{KOH}$, and 10 drops of $37 \%$ HCHO. Heat to boiling to coagulate the metallic $\mathrm{Ag}$ precipitate. Add 4 drops of $0.1 \mathrm{M} \mathrm{AgNO}_{3}$ and again remove a Ag precipitate. Filter both Ag precipitates together through No. 40 Whatman filter paper in a $2^{18}, 60^{\circ}$ funnel, collecting the filtrate in a $125 \mathrm{mI}$ Erlenmeyer Plask.

Step 7. Acidify the filtrate with conc. HNO 3 , add an additionsl $2 \mathrm{ml}$ of the acid, and heat to boiling (Note 2). Cool and add 4 drops of KI carrier solution. Transfer to a $125 \mathrm{ml}$ separatory funnel, add $50 \mathrm{ml}$ of $\mathrm{CCl}_{4}$ and a few crystals of $\mathrm{KNO}_{2}$. Extract $\mathrm{I}_{2}$ into the $\mathrm{CCI}_{4}$ layer and discard. Add three separate additional 10-ml portions of $\mathrm{CCI}_{4}$, extract $\mathrm{I}_{2}$, and discard the $\mathrm{CCl}_{4}$ Iayer after each extraction.

Step 8. To the remaining aqueous layex add 2-3 ce of conc. $\mathrm{HNO}_{3}$, transfer to a 40-mi centrifuge tube, and heat to boiling to remove excess $\mathrm{NO}_{2}^{-}$ion. Add 4 drops of Fe carrier and precipitate $\mathrm{Fe}(\mathrm{OH})_{3}$ with conc. 
$\mathrm{NH}_{4} \mathrm{OH}$. Centrifuge, transfer the supernate to a clean centrifuge tube, and discard the precipitate.

Step 9. Again add 4 drops of $\mathrm{Fe}$ carrier and remove a $\mathrm{Fe}(\mathrm{OH})_{3}$ scavenger precipitate as in the previous step.

Step 20. To the $\mathrm{CI}$-containing supernate add $0.1 \mathrm{M} \mathrm{AgNO}_{3}$ to preclpitate AgCI. Centrifuge and wash the precipitate as in step 4.

Step 1l. Dissolve the $\mathrm{AgCl}$ precipitate in $2 \mathrm{ml}$ of conc. $\mathrm{NH}_{4} \mathrm{OH}$. Wash with several $\mathrm{ml}$ of $\mathrm{H}_{2} \mathrm{O}$ into a special distilling flask (see diagram of multiple still). Bubble air through the solution to remove most of the $\mathrm{NH}_{4} \mathrm{OH}$. Cautiously add $6 \mathrm{ml}$ of conc. $\mathrm{H}_{2} \mathrm{SO}_{4}$ (Note 3) and heat until all the $\mathrm{HCl}$ has distilled over into a $50 \mathrm{ml}$ beaker containing $20 \mathrm{ml}$ of $\mathrm{H}_{2} \mathrm{O}$.

Step 12. Precipitate $\mathrm{Hg}_{2} \mathrm{Cl}_{2}$ from the solution of $\mathrm{HCl}$ distillate (after adding 1-2 $\mathrm{ml}$ of conc. $\mathrm{HNO}_{3}$ ) by the dropwise addition of $0.1 \mathrm{M}$ $\mathrm{Hg}_{2}\left(\mathrm{NO}_{3}\right)_{2}$ solution. Wash the precipitate with $\mathrm{H}_{2} \mathrm{O}$ after filtering on a tared No. 42 Whatman filter circle, $7 / 8^{\prime \prime}$ diameter, using the standard chimney technique. Wash with absolute $\mathrm{C}_{2} \mathrm{H}_{5} \mathrm{OH}$ and dry in an oven for 20 minutes at $110^{\circ}$. Cool, weigh, mount, and count (Note 4).

\section{Notes}

1. If the radiochlorine is originally in a form other than $\mathrm{Cl}^{-}$ion or $\mathrm{Cl}_{2}$, care must be taken to reduce it to one of these forms before beginning the procedure. Otherwise the radiochlorine may be lost as a result of its fallure to exchange with $\mathrm{Cl}^{-}$carrier. The total volume in step 1 should not exceed $20 \mathrm{ml}$.

2. Boiling is necessary at this stage to remove most of the volatile HCHO.

3. Addition of conc. $\mathrm{H}_{2} \mathrm{SO}_{4}$ precipitates $\mathrm{AgCl}$. During distillation continue bubbling air through the solution.

4. $\mathrm{Hg}_{2} \mathrm{Cl}_{2}$ is used as the compound mounted in preference to $\mathrm{AgCl}$ because it does not form agglomerates as does $\mathrm{AgCl}$. $\mathrm{PbCl}_{2}$ is too soluble and therefore not suitable. For counting $4 \times 10^{5}$ y $\mathrm{Cl}^{36}$, a self-absorption curve should be constructed and corrections applied for a $0.72 \mathrm{Mev} \beta^{-}$. 
Source - W. W. Meinke, report ABCD-2738, pp. 95. Aug. 1949

Element separated: Bromine

Target material: $\sim 1.8 \mathrm{BI}$ metal

Type of bbdt: $184^{\prime \prime}$ all particles
Procedure by: Goeckermann

Time for sep $n$. 1-2 hrs.

Equipment required: Centr1fuge, tubes, $110^{\circ}$ oven

Yield: $\quad-60 \%$

Degree of puriflcation: Decontamination factor $\sim 10^{4}$ from fission and spellation products.

Advantages: Good yleld of pure Br.

Procedure:

(1) To allquot of $\mathrm{kNO}_{3}$ soln of target, add $10 \mathrm{mg} \mathrm{Bx} \mathrm{Bx}^{-\infty}$ and $\mathrm{I}^{-}$, make $I \mathrm{~N}$ in $\mathrm{HNO}_{3}$, add a few drops of $0.1 \mathrm{M} \mathrm{NaNO} \mathrm{N}_{2}$, and extract $\mathrm{I}_{2}$ into equal vol $\mathrm{CCl}_{4}$.

(2) Add equal vol $\mathrm{CCl}_{\text {. }}$ to aqueous phase and add $0.1 \mathrm{M} \mathrm{KnO}_{4}$ dropwise unt1l color persists. Make five extractions of $\mathrm{Br}_{2}$.

(3) Combine $\mathrm{CCl}$ s layers and wash with $1 \mathrm{~N} \mathrm{HWO}_{3}$ contalning $\mathrm{MnO}_{4}$. Add $10 \mathrm{ml} \mathrm{H}_{2} \mathrm{O}$ and 0.1 N $\mathrm{NaHSO}_{3}$ dropwise until both layers are coloriess. Wash aq layer with $\mathrm{CCl}_{4}$.

(4) Make I I In $\mathrm{HNO}_{3}$, add $\sim 10 \mathrm{mg} \mathrm{I}^{-}$, warm a few min to oxidize $50_{3}^{=}$, add few drops $0.1 \mathrm{M} \mathrm{NamO}$ and extrect $\mathrm{I}_{2}$ flve times with $10 \mathrm{ml}$ $\mathrm{CCI}_{\text {. }}$.

(5) Repeat $\mathrm{KMnO}_{4}$ oxidation and $\mathrm{Br}_{2}$ extrn and reduction.

(6) Repeat $\mathrm{I}_{2}$ and $\mathrm{Br}_{2}$ extron cycles as needed for purity.

(7) Make last aq soln of $\mathrm{Br}^{\mathrm{IN}}$ in $\mathrm{HNO}_{3}$, heat, add $2 \mathrm{ml} 0.1 \mathrm{~N} \mathrm{AgNO}_{3}$ stir, digest few min, PIIter, wash three times with $5 \mathrm{ml} \mathrm{H} \mathrm{H}_{2}$, EtOH, and ether, dry 10 min at $110^{\circ} \mathrm{C}$. Welgh as AgBr (23.5 mg per $10 \mathrm{mg} \mathrm{Br}$ ).

Remarks: The biamuth fission work only required three $I_{2}-B_{2}$ extrn cycles. To prevent possible losses of trece Br during dissolving of the bismath, one might dissolve the target in $6 \mathrm{~N} \mathrm{HNO}_{3}$ with the carrier $\mathrm{Br}^{-}$present in a glass still, and distill $\mathrm{Br}_{2}$ or $\mathrm{BBr}$ directly from this soln into Hi. $\mathrm{O}$ in an ice bath. 
Source - W. W. Meinke, report AECD-2738, pp. 96. Aug. 1949

Element separated: Bromine

Target material: Tantalum

Type of bbdt: $\mathrm{Ta}+350 \mathrm{Mev}$ protons
Procedure by: Iindner

Modified by: Neumann

Time for sep'n: 2 hours

Equigment required: sep.

funnel

Yield: $\sim 40 \%$

Degree of purification: excellent - factor of $\sim 10^{4}$ from fission and spallation products.

Advantages: Provides for the separation of $\mathrm{Br}_{2}$ from targets requiring $\mathrm{HF}-\mathrm{HNO}_{3}$ mixtures for solution of the target. In these cases glass equipment is impossible and the method of distillation of the halogens is impractical.

Procedure:

(1) Freshly precipitated $\mathrm{AgBr}$ (well washed to remove excess $\mathrm{Ag}^{+}$) containing $10 \mathrm{mgs}$ of bromine as silver bromide is added to 15 $m$ ls of $48 \% \mathrm{HF}$ solution contained in a lusteroid test tube. The target foil is placed in solution and conc. $\mathrm{HNO}_{3}$ is added as required for solution of the foil. (See (a) under remarks.)

(2) After target has dissolved the solution is allowed to stand for 15 minutes, (See (b) under remarks.) the supernatant target solution is removed, the $\mathrm{AgBr}$ washed twice with $10 \mathrm{mls}$ hot water, $10 \mathrm{mls}$ of water is added and the slurry is saturated with $\mathrm{H}_{2} \mathrm{~S}$, then centrifuged.

(3) The supernatant solution is bolled to remove $\mathrm{H}_{2} \mathrm{~S}, 10 \mathrm{mgs} \mathrm{I}^{-}$is added, the solution is made $I N$ in $\mathrm{HNO}_{3}$ a few drops of $\mathrm{NaNO}_{2}$ is added and the iodine extracted into $10 \mathrm{mls}$ of $\mathrm{CCl}_{4}$. (extract a total of 5 times).

(4) $10 \mathrm{mls}$ of $\mathrm{CCl}_{4}$ is added to the aqueous phase and $0.1 \mathrm{M} \mathrm{KMnO}_{4}$ solution is added until the bromine color persists. Extract $\mathrm{Br}_{2} 5$ times (total).

(5) Combine the $\mathrm{Br}_{2}-\mathrm{CCl}_{4}$ extract, wash with I N $\mathrm{HNO}_{3}$ containing $\mathrm{KMnO}_{4}$, add $10 \mathrm{mls} \mathrm{H}_{2} \mathrm{O}$ and $0.1 \mathrm{~N} \mathrm{NaHSO}_{3}$ dropwise until both layers are colorless. (See (c) under remarks.) Wash aqueous layer with $\mathrm{CCl}_{4}$.

(6) Make $1 \mathrm{~N}$ in $\mathrm{HNO}_{3}$ add $10 \mathrm{mgs} \mathrm{I}^{-}$, warm for a few minutes to oxidize the $\mathrm{SO}_{3}$, add a few drops of $0.1 \mathrm{M} \mathrm{NaNO}_{2}$ and extract the $\mathrm{I}_{2} 5$ times with $\mathrm{CCl}_{4}$.

(7) Repeat (4) and (5) as needed (A total of 3 times was used for purification above.) 
(8) Make last aqueous solution of $\mathrm{Br}^{-}$I N in $\mathrm{HNO}_{3}$, heat, add 2 mis $0.1 \mathrm{~N} \mathrm{AgNO}_{3}$. Stir, digest a few minutes, wash three times with 5 mls $\mathrm{H}_{2} \mathrm{O}, 5 \mathrm{mls} \mathrm{C}_{2} \mathrm{H}_{5} \mathrm{OH}, 5 \mathrm{mls}$ ether. Dry for $10 \mathrm{mins}$ at $110^{\circ} \mathrm{C}$.

Remarks :

(a) This reaction proceeds rapidiy and at no time should there be and excess of HINO$_{3}$. Heating is not required and lusterold tube may be ice cooled if necessary.

(b) Procedure depends upon an equilibration between $\mathrm{ABBr}$ and tracer bromide ion in the target solution. If the tracer bromine vere in a higher oxidation state this equilibration would be impossible. However, since the Ta is being dissolved it may be assumed reductive conditions exist and all the tracer is in the form of bramine or bromide.

(c) Unless the solution is kept acid $\mathrm{MnO}_{2}$ will precipitate. The $\mathrm{MnO}_{2}$ precipitation may also be avolded if the solution is warmed before permanganate addition.

(d) Steps (3) and (9) are R. H. Goeckermann's procedure for bromine.

(e) $I_{2}$ might also be separated by this procedure.

PROCEDURE 6 - BRCMINE

Source - W. W. Meinke, report AECD-2738, pp. 98. Aug. 1949

Element separated: Bromine

Target material: Thorium metal (.1-1 gm)

Type of bbdt: $60^{\text {" metal }}$

Yield: $\sim 50 \%$

Degree of purification: $\sim 10^{6}$ except from $I^{-}\left(\sim 10^{4}\right.$ from $\left.I^{-}\right)$

Procedure: The Th metal is dissolved in conc. HCI + a few drops .2 M solution $\left(\mathrm{NH}_{4}\right)_{2} \mathrm{SiF}_{6}$ to clear up black residue. The $\mathrm{HCl}$ is diluted to $2 \mathrm{~N}$ and an aliquot taken. Sample added to $15 \mathrm{mI} 1 \mathrm{~N} \mathrm{HNO}_{3}$ in 50 ml separatory funnel. Add $10 \mathrm{mg} \mathrm{Br}^{-}$carrier and $10 \mathrm{mg} \mathrm{I}^{-}$carriex.

(1) Add $\mathrm{KmO}_{4}$ (0.1N) dropwise until color persists (15 drops). Make 5 successive extractions with $\mathrm{CCl}_{4}$. Discard aqueous. To $\mathrm{CCl}_{4}$ layer add $10 \mathrm{ml}$ water and $0.2 \mathrm{~N} \mathrm{NaHSO}_{3}$ until $\mathrm{CCl}_{4}$ layer colorless on shaking. Discard the CCls.

(2) To aqueous add $2 \mathrm{ml} \mathrm{HNO}_{3}$ and $10 \mathrm{mg} \mathrm{I}^{-}$, add 4 drops of $0.1 \mathrm{M}$ $\mathrm{NaNO}_{2}$. Extract five times with $\mathrm{CCI}_{3}$. Add more $\mathrm{I}^{-}$and repeat extraction with four more portions of $\mathrm{CCl}_{4}$.

(3) Add $\mathrm{KMnO}_{4}$ to oxdidize $\mathrm{Br}^{\circ}$. Extract five times with $\mathrm{CCl}_{4}$. 
(4) Extract $\mathrm{CCl}_{4}$ with $\mathrm{NaHSO}_{3}$. $\mathrm{Add} \mathrm{Ag}^{+}$to $\mathrm{gpt} \mathrm{AgBr}$. Filter, wash three times with $5 \mathrm{ml} \mathrm{H} \mathrm{H}^{\circ}$ and three times with $5 \mathrm{ml} \mathrm{EtOH.} \mathrm{Dry}$ at $110^{\circ}, 10 \mathrm{~min}$ and welgh. $10 \mathrm{mg} \mathrm{Br}=23.5 \mathrm{mg} \mathrm{AgBr}$.

Remarks: This method has been described previously (Phys. Rev. 15, 17 (1949)).

\section{PROCEDURE 7 - BROMINE}

Source - Glendenin, Edwards and Gest, N.N.E.S., Vol. 9, Book 3, pp. 1451

\section{Introduction}

Bromine is separated from the other fission products by the reductIon of $\mathrm{BrO}_{3}^{-}$carrier to $\mathrm{Br}^{-}$with $\mathrm{H}_{2} \mathrm{~S}$, followed by oxidation to $\mathrm{Br}_{2}$ with $\mathrm{MnO}_{4}$, and extraction into $\mathrm{CCl}_{4}$. The $\mathrm{Br}_{2}$ is removed from the $\mathrm{CCl}_{4}$ by shaking with water containing $\mathrm{NH}$ OH.HCI. The aqueous solution is then purified by two more $\mathrm{CCl}_{4}$ extraction cycles, using $\mathrm{KMnO}_{4}$ for oxidation to $\mathrm{Br}_{2}$ and using $\mathrm{NaHSO}_{3}$ for reduction to $\mathrm{Br}^{-}$. The bromine is inally precipitated as ABBr for weighing and counting.

The reduction of $\mathrm{BrO}_{3}^{-}$to $\mathrm{Br}^{-}$with $\mathrm{H}_{2} \mathrm{~S}$ ensures the interchange of radiobromine with the carrier. 35 Failure to achieve a complete interchange has been observed in previous methods of bromine separation. 36,37 The use of $\mathrm{NH}_{2} \mathrm{OH} . \mathrm{HCl}$ to reduce $\mathrm{Br}_{2}$ to $\mathrm{Br}^{-}$in the first extraction cycle helps to decontaminate the bromine frcm lodine, since $\mathrm{NH}$ reduce $I_{2}$ to $I^{-}$. Contamination by other fission activities, including lodine, is negligible. The chemical yield is 50 per cent or more, and the time required for a complete analysis is about $1 \mathrm{hr}$.

\section{Procedure}

Step 1. To not more than $5 \mathrm{ml}$ of a solution of neutron-irradiated uranyl nitrate (Note 1) in a 50-ml centrifuge tube, add $20 \mathrm{mg}$ of bromine carrier as $\mathrm{BrO}_{3}^{-}$and $10 \mathrm{mg}$ of lodine carrier as $\mathrm{IO}_{3}^{-}$. Pass in $\mathrm{H}_{2} \mathrm{~S}$ for 1 to 2 min (Note 2), boil briefly to expel the $\mathrm{H}_{2} \mathrm{~S}, \mathrm{cool}$, and transfer the solution to a $60-\mathrm{ml}$ separetory funnel.

Step 2. Add $1 \mathrm{ml}$ of $6 \mathrm{M} \mathrm{HNO}_{3}$ and a few drops of $1 \mathrm{M} \mathrm{KMnO}_{4}$ (Note 3), extract the $\mathrm{Br}_{2}$ into $10 \mathrm{ml}$ of $\mathrm{CCl}_{4}$, and discard the aqueous layer.

Step 3. Shake the $\mathrm{CCl}_{4}$ layer with $10 \mathrm{ml}$ of $\mathrm{H}_{2} \mathrm{O}$ containing $1 \mathrm{ml}$ of IM $\mathrm{NH}_{2} \mathrm{OH} . \mathrm{HCl}$, and discard the $\mathrm{CCl}_{4}$.

Step 4. Repeat Step 2.

Step 5. Shake the $\mathrm{CCl}_{4}$ layer with $10 \mathrm{ml}$ of $\mathrm{H}_{2} \mathrm{O}$ containing a few drops of $\mathrm{IM} \mathrm{NaHSO}_{3}$, and discard the $\mathrm{CCl}_{4}$. 
Step 6. Repeat Step 2.

Step 7. Repeat Step 5.

Step 8. Add I ml of $6 \mathrm{HNO}_{3}$, and heat nearly to bolling (Note 4). Add $2 \mathrm{ml}$ of $0.2 \mathrm{M} \mathrm{AgNO}_{3}$ drop by drop with stirring and digest the precipitate of AgBr for a few seconds. Filter with suction on a weighed I1Iterpaper disk (Note 5) in a sull Hirsch funnel, and wash three times with $5 \mathrm{ml}$ of $\mathrm{Hz} \mathrm{O}$ and three times with $5 \mathrm{ml}$ of ethanol. Dry at $110^{\circ} \mathrm{C}$ for 10 min, weigh as AgBr, and mount.

Notes. 1. The sample solution should be neutrel or slightly acidic.

2. The presence of $\mathrm{HNO}_{3}$ in the sample will cause the formation of free sulfur at this point. This does no haw, since the sulfur is left behind during the $\mathrm{CCl}_{4}$ extraction cycles.

3. Sufficient $\mathrm{KMnO}_{4}$ should be added to maintain a permanent purple color.

4. The solution is acidified and heated to expel $\mathrm{SO}_{2}$, which might interfere in the AgBr precipitation.

5. The f1lter-paper disk is washed with ethanol and dried undex the conditions of the procedure before the weighing.

\section{PROCEDURE 8 - BROMTIVE}

Source - R. Overstreet and I. Jacobson, N.N.E.S., Vol. 9, Book 3, pp. 1453

Selenium metal was fused on a copper cyclotron target and bombarded in a bell jar with deuterons at the Berkeley cyclotron. The selenium is dissolved in conc. $\mathrm{HNO}_{3}$. The solution is diluted to $6 \mathrm{M}$, and the acid is distilled from the solution. The distillate, containing $\mathrm{Br}^{82}$, is collected in $\mathrm{CCl}_{4}$, waich is then washed three times with distilled water. Sufficient $\mathrm{Cl}_{2}$ gas is added to the $\mathrm{CCl}_{4}$ to produce a definite yellow color, and the mixture is placed in direct sunlight for at least $1 \mathrm{hr}$. At the end of this period the $\mathrm{CCl}_{4}$ mixture is extracted with an excess either of $\mathrm{Na}_{2} \mathrm{SO}_{3}$ or of $\mathrm{Na}_{2} \mathrm{~S}_{2} \mathrm{O}_{3}$ to give a solution of tracer bromine free of signiflcant amounts of bromine carrier. 
Source - R. R. Edwards and H. Gest, N.N.E.S., Vol. 9, Book 3. pp 1454

In connection with studies on the chemical effects associated with the formation of bromine from the decay of selenium 38 on the behavior of of bromine at tracer concentrations, 39 several interesting reactions were studied which are reported briefly here.

Tracer bromine solutions were prepared by the neutron irradiation of degassed $\mathrm{KBrO}_{3}$ and the extraction of the water solution by $\mathrm{CCl}_{4}$ in the presence of $\mathrm{HNO}_{3}$ and $\mathrm{KMnO}_{4}$. About 60 per cent of the $34 \mathrm{~b} \mathrm{Br}{ }^{82}$ is found in the $\mathrm{CCl}_{4}$ layer. Reextraction into a water layer with $\mathrm{NaHSO}_{3}$ gives a solution of $\mathrm{Br}^{-}$concentration of the order of $10^{-10} \mathrm{M}$, since $\mathrm{Ag}^{+}$ gives no precipitate or centrifugable colloid. ${ }^{39}$ A large Praction (about 70 per cent) of the bromine activity can be extracted from the $\mathrm{CCl}_{4}$ solution by water, presumably because of the hydrolysis of $\mathrm{Br}_{2}$ to $\mathrm{Br}^{-}$and $\mathrm{BrO}^{-}$. An appreciable fraction (about 16 per cent) is not extracted by water but is extracted by $\mathrm{NaHSO}_{3}-\mathrm{KBr}$ solution, as found by Devault and Libby. 40 This fraction also reacts in the absence of light with ethylidene bromide, $\mathrm{CH}_{3} \mathrm{CHBB}_{2}$, a reaction characteristic of bromine atoms and not of $\mathrm{Br}_{2}$. This fraction is provisionally designated as "htomic bromine, although atomic bromine is not expected to be present in appreciable amounts even in these dilute solutions unless it is highly stabilized by complex formation with the solvent. In addition, a small fraction of the activity is bound by the purified $\mathrm{CCl}_{4}$, and a roughly equal fraction is lost, perhaps to the wall; these losses may be due to B-radiation effects. Extensive studies of the reactivity of the tracer are presented elsewhere. 39

With the aid of water solutions of the tracer extracted from the $\mathrm{CCl}_{4}$ solution, it was shown that 96 to 99 per cent of the activity is collected by freshly prepared $A g B r$ in 10 to $45 \mathrm{~min}$ of stirring. Kolthoff and $0^{\prime} \mathrm{Brien} / \mathrm{l}$ have shown that freshly precipitated $\mathrm{AgBr}$ exchanges rapidly with $\mathrm{Br}^{-}$at ordinary concentrations; this experiment shows that $\mathrm{BrO}^{-}$also exchanges readily at concentrations below $10^{-10} \mathrm{M}$.

Bromine tracer does not exchange appreciably with $0.13 \mathrm{M} \mathrm{KBrO}_{3}$ after standing for 10 to $100 \mathrm{~min}$ at room temperature in a neutral solution, as shown by the complete recovery of the activity with added AgBr precipitate. 
Source - W. W. Meinke, report AECD-3084, pp. 21. March, 1951

Element separated: Iodine

Target material: Te (2 Ibs.)

Frou natural radioactive Te (8)

Yleld: $60 \%$

Degree of purification: At least $10^{\circ}$ from Te

Procedure:

(1) Te metal was oxldized by conc. $\mathrm{HNO}_{3}$ to $\mathrm{TeO}_{2}$ which was fused with NaOE. The fused mass was dissolved in water.

(2) $10 \mathrm{mg}$ of $I^{-m}$ and $20 \mathrm{mg} \mathrm{Br}^{-}$were added as carriers to the solution. $\mathrm{AgNO}_{3}$ was added slowly to excess to ppt AgI and AgBr, avolding precipitation of $\mathrm{Ag}_{2} \mathrm{O}$.

(3) Ppt was obtained by centrifuging the solution and then treating with $1 \mathrm{gm}$ of $\mathrm{K}_{2} \mathrm{Cr}_{2} \mathrm{O}_{7}$ and $15 \mathrm{ml}$ of $\mathrm{H}_{2} \mathrm{SO}_{4}$. The mixture was dgested for 30 minutes at $95^{\circ} \mathrm{C}$.

(4) A stream of air bus bubled through the solution for 15 minutes and then the solution was cooled and treated with conc. $\mathrm{Na}_{2} \mathrm{SO}_{3}$ solution slowly until a faint odor of $\mathrm{SO}_{2}$ remained after standing 10 minutes.

(5) $\mathrm{AgI}$ was ppted by adding $\mathrm{AgNO}_{3}$ to the mixture.

Remarks:

Iodine was milked from natural Te.

See: Scott's Standard Methods of Chemical Analysis, page 276.

\section{PROCEDURE II - IODINE}

Source - W. W. Meinke, report AECD-2738, pp. 161. Aug. 1949

Element separated: $I\left(\sim 10^{-6}\right.$ barns cross

Procedure by: Marquez section)

Target material: $\sin (\sim 1 \mathrm{gm})$

Time for sep in: 50 min.

Yield: $70-80 \%$

Type of bbdt: $184 \alpha$ and $p$

Equipment required: 100 cc dist1llation flask separatory funnels centrifuge tubes

Degree of purification: Less than $1 \%$ impurity in final I sample. Advantages: Fast. Makes possible sep'n of a very small amount of pure I from large amounts of other activities. 
Procedure:

(1) Add 10 ms I' carrier and target foll to distillation Plask.

(2) Add $\sim 15 \mathrm{ml}$ conc. $\mathrm{H}_{2} \mathrm{SO}_{4} ;\left(\mathrm{H}_{2} \mathrm{SO}_{4}\right.$ should be cold) to dissolve the $\mathrm{Sn}$.

(3) Dissolve Sn and distill simultaneously, collecting $I_{2}$ in $0.5-I N$ NaOH solution.

(4) Acidify with $\mathrm{H}_{2} \mathrm{SO}_{4}$ until lodine turns brow and oxidize with $\mathrm{HNO}_{2}$, ( $\mathrm{NaNO}_{2}$ in acid solution). Extract with equal volume $\mathrm{CCl}_{4}$.

(5) Wash $\mathrm{I}^{-}$into $\mathrm{NaOH}$ solution.

(6) Repeat $\mathrm{NaOH}-\mathrm{CCl}_{4}$ cycles as many times as wished. (Turee cycles gave purity insted above.)

(7) Acidify last $\mathrm{NaOH}$ solution with $\mathrm{H}_{2} \mathrm{SO}_{4}$ and reduce with $\mathrm{SO}_{2}$ gas. Blow air through solution to expel most of $\mathrm{SO}_{2}$. Add excess Agt and a few drops of conc. $\mathrm{HNO}_{3}$.

(8) Heat in water bath and filter.

(9) Plate and count as AgI.

Remarks:

Most of the loss in this procedure comes in the distillation process. Ice cold $\mathrm{H}_{2} \mathrm{SO}$ used in (2) to allow assembly of distillation apparatus before solution of target starts.

$\mathrm{SO}_{2}$ solutions can be used to collect the $\mathrm{I}_{2}$ from the distillation. The solution is then oxidized with $\mathrm{HNO}_{2}$ and the $\mathrm{I}_{2}$ extracted went equal volume of $\mathrm{CCl}_{4}$. The $\mathrm{I}_{2}$ washed out of the organic layer into $\mathrm{SO}_{2}$ solution and the cycle repeated. This " $\mathrm{SO}_{2}$ procedure is troublesome in the experiments above because the solution develops a gas pressure during the extractions.

\section{PROCEDURE 12 - IODINE}

Source - W. W. Meinke, report AECD-2738, pp. 162. Aug. 1949

Element separated: Iodine

Target material: $\mathrm{Sb}(\sim 500 \mathrm{mg})$

Type of bbdt: $60^{\mathrm{m}} \alpha$ particles
Procedure by: Marquez Time for sep'n: -40 min. Equipment required: 100 distillation flasks sep funnels and centrifuge tubes

Yield: $80 \%$ or higher

Degree of purification: At least a factor of $10^{4}$ from other activities present.

Advantages: Fast and good separation. 
Procedure:

(1) Add target, $10 \mathrm{mg} \mathrm{I}$ carrier, 10-15 ml of saturated tartaric acid and 10-15 ml of ice cold $\mathrm{HrO}_{3}$ to distillation apparatus.

(2) Distil and collect $I_{2}$ in $0.5-1 \mathrm{~N} \mathrm{NaOH}$.

(3) Acidify with $\mathrm{H}_{2} \mathrm{SO}_{4}$ until lodine turns brown and oxidize with $\mathrm{HNO}_{2},\left(\mathrm{NaNO}_{2}\right.$ in acid solution). Extract with equal volume $\mathrm{CCl}_{4}$.

(4) Wash I' into NaOH solution.

(5) Repeat $\mathrm{NaOH}-\mathrm{CCl}_{4}$ cycles as many times as wished. (Three cycles gave purity listed above,)

(6) Acidify last $\mathrm{NaOH}$ solution with $\mathrm{H}_{2} \mathrm{SO}_{4}$ and reduce with $\mathrm{SO}_{2}$ gas. Blow air through solution to expel most of $\mathrm{SO}_{2}$. Add excess $\mathrm{Ag}+$ and a few drops of conc. $\mathrm{HNO}_{3}$.

(7) Heat in water bath and filter.

(8) Plate and count as AgI.

Remarks:

Most of the loss in this procedure comes in the distillation process.

Ice cold $\mathrm{ENO}_{3}$ used in (1) to allow assembly of distillation apparatus before solution of target starts.

Solution of So in aqua regia interferes with $I_{2}$ extraction.

An I' sample could be obtained in 15-20 min by ppting the AgI directly from the distiliate of (2). The radioactive purity of the sample, however, will not be as high as above.

$\mathrm{SO}_{2}$ solution can be used to collect the In from the distillation. The solution is then oxidized with $\mathrm{kNO}_{2}$ and the $\mathrm{I}_{2}$ extracted with equal volume of $\mathrm{CCI}_{4}$. The $\mathrm{I}_{2}$ washed out of the organic layer lnto $\mathrm{SO}_{2}$ solution and the cycle repeated.

\section{PROCEDURE 13 - IODINE}

Source - W. W. Meinke, report AECD-2738, pp. 163. Aus. 1949

Element separated: Iodine

Target material: $\sim$ I \& Bi metal

Type of bbdt: 184 a.1 particles
Procedure by: Goeckermann Time for sep'n: -2 hrs.

Equipment required: Distiliztion flask, centroifuge, tubes, 1 ce, $110^{\circ}$ oven.

Yield: Approx. 40\%

Degree of purification: Decontamination factor $>10^{4}$ from fission and spallation products.

Advantages: Fair yield of pure I with little if any non-exchange trouble. 
Procecunre:

(1) Place target in glass still, add $10 \mathrm{mg} \mathrm{I}$ and $10 \mathrm{mI}$ 6N $\mathrm{HNO}_{3}$, warm to dissolve. When entirely dissolved, distill over the $I_{2}$ and a few $m$ l $\mathrm{HNO}_{3}$ into $\mathrm{H}_{2} \mathrm{O}$ in an ice bath.

(2) Reauce $\mathrm{I}_{2}$ with a minimm of $\mathrm{NaHSO}_{3}$ in the cold, adjust, to $0.5 \mathrm{~N}$ $\mathrm{HNO}_{3}$, add a few drops $0.1 \mathrm{M} \mathrm{NaNO}_{2}$, and extract $\mathrm{I}_{2}$ into an equal volume of $\mathrm{CCl}_{4}$. Bxtract aqueous with second portion $\mathrm{CCl}_{4}$. Wash $\mathrm{CCI}_{4}$ with dilute $\mathrm{HNO}_{3}$.

(3) Slave $\mathrm{CCl}_{4}$ with $10 \mathrm{ml} \mathrm{H}_{2} \mathrm{O}$, adding $\mathrm{NaHSO}_{3}$ untIl both phases colorless. Wash aqueous with $\mathrm{CCl}_{4}$.

(4) Repeat extraction cycle several times.

(5) Make last aqueous $\mathrm{I}^{-}$solution $0.5 \mathrm{M}$ in $\mathrm{HNO}_{3}$, heat to boiling, add $2 \mathrm{mI} 0.1 \mathrm{~N} \mathrm{AgNO}_{3}$, digest, filter, wash three times with $\mathrm{H}_{2} \mathrm{O}$, three times with $5 \mathrm{mI} \mathrm{C} \mathrm{C}_{2} \mathrm{H}_{5} \mathrm{OH}$, three times with $5 \mathrm{ml}$ other, dry $10 \mathrm{~min}$ at $110^{\circ} \mathrm{C}$. Weigh as AgI ( $18.50 \mathrm{mg}$ per $10 \mathrm{mg} I$ ).

Remarks: Active lodin formed as periodate may not exchange with the carrier by this method, although the I yields were not abnomally low. Reducing condition probably prevail during dissolution of the target.

\section{PROCEDURE 14 - IODINE}

Source -W. W. Meinke, report AECD-2738, pp. 164. AuB. 1949

Element separated: Iodine

Terget material: Throitm metal $(.1-1 \mathrm{gm})$

Type of bbdt: $60^{\text {"B }} \alpha^{\text {s }}$

Xield: $90 \%$

Degree of purification: $10^{6}$

Procedure: The Th metal is dissolved in conc. HCl + a few arops $2 \mathrm{M}$ solution $\left(\mathrm{NH}_{4}\right)_{2} \mathrm{SIF}_{6}$ to clear up black residue. The HCl is diluted to $2 \mathrm{~N}$ and an aliquot taken.

\section{Procedure:}

(1) Add sample to $10 \mathrm{ml} 2 \mathrm{M} \mathrm{Na}_{2} \mathrm{CO}_{3}{ }^{(1)}$. Add $20 \mathrm{mg} \mathrm{I}^{-}$In $60 \mathrm{ml}$ sep funnels. Add $2 \mathrm{ml} \mathrm{2.5 \%} \mathrm{NaOCl}{ }^{(2)}$. Heat. Acidify with $3 \mathrm{ml}$ conc. $\mathrm{HNO}_{3}$, add $3 \mathrm{ml} I \mathrm{M} \mathrm{NH} 2 \mathrm{OH} \cdot \mathrm{HCl}$ (3) Extract with $10 \mathrm{ml} \mathrm{CCl}_{4}$.

(2) Shake with $10 \mathrm{ml} \mathrm{H}_{2} \mathrm{O}$ containing a fev drops $\mathrm{NaHSO}_{3}$ wntil both phases colorless.

(3) To water add $1 \mathrm{ml} 6 \mathrm{~N} \mathrm{HNO}$ and a few drops of $1 \mathrm{M} \mathrm{NaNO}_{2}$. Extract into $\mathrm{CCl}_{4}$. 
(4) Repeat (2).

(5) Add I ml $6 \mathrm{~N} \mathrm{HNO}_{3}$. Heat to boiling. Add $2 \mathrm{ml} 0.1 \mathrm{~N} \mathrm{AgHO}_{3}$. Stix and digest. Filter on tared filter paper. Wash three times with $5 \mathrm{ml} \mathrm{H} 2 \mathrm{O}$, three times with $5 \mathrm{ml}$ BtOH and three times with $5 \mathrm{ml} \mathrm{Et} \mathrm{H}_{2} \mathrm{O}$. Dry at $110^{\circ} \mathrm{C}$ for $10 \mathrm{~min}$. Welgh as AgI.

Remarks: $10 \mathrm{mg} I=18.42 \mathrm{mg} \mathrm{AgI}$

(1) If $\mathrm{BI}$ and Ia present add $1 \mathrm{ml}$ of $10 \%$ tartaric acid and $19 \mathrm{M} \mathrm{NaOH}$.

(2) oxidize $I^{-}$to $\mathrm{IO}_{4}^{-}$. Solution mst be heated, preferably boiled 5 minutes for complete exchange to occur.

(3) Reduce $\mathrm{IO}_{4}^{-}$to $\mathrm{I}_{2}$.

This method has been described previously (Phys. Rev. 75, 17 (1949)).

Preparation of carrier solution: Dissolve 13 gms $K I$ in water containing a trace of $\mathrm{NaHCO}_{3}$. Dilute to one liter.

Standardization: Take $5 \mathrm{ml}$ carrier solution in beaker. Add $50 \mathrm{ml}$ $\mathrm{H}_{2} \mathrm{O}$ and $1 \mathrm{ml} 6 \mathrm{~N} \mathrm{HNO}_{3}$. Heat nearly to bolling and add $5 \mathrm{ml} 0.1 \mathrm{~N} \mathrm{HgNO}_{3}$ with stirring. Digest 1 minute. Filer into a sintered glass cructble, wash three times with $\mathrm{H}_{2} \mathrm{O}$, three times with $95 \% \mathrm{E}$ toH. Dry at $110^{\circ} \mathrm{C}$ and weigh as AgI.

PROCIEDURE IS - IODTIEE

Source - L. E. Glendenin and R. P. Metcalf, N.N.E.S., Val. 9, Book 3, pp 1625

\section{Introduction}

A widely used method for direct separation of radioactive lodine from the other flssion products is the $\mathrm{CCl}_{4}$ extrection of iodine in the elementary state. 42,43 Extensive work on the problem of Interchange 3 bas shown that preliminary steps to effect complete interchange between tracer iodine and carrier lodine are required before the separation by $\mathrm{CCl}_{4} \mathrm{ex}-$ traction can be made. A satisfactory method of achieving the required interchange was developed; it consists in the oxidation of $I^{-}$carrier to $\mathrm{IO}_{4}^{-}$(periodate) with NaCIO in alkaline solution. This reaction has been incorporated into the present procedure. After the interchange reaction the solution is acidified, the $\mathrm{IO}_{4}^{-}$is reduced to $\mathrm{I}_{2}$ with hydroxylamine hydrochloride ( $\mathrm{NH}_{2} \mathrm{OH} . \mathrm{HCl}$ ), and the $I_{2}$ is extracted with $\mathrm{CCI}_{4}$. The $I_{2}$ is removed from the $\mathrm{CCl}_{4}$ by shaking with water containing $\mathrm{NaHSO}_{3}$ and is then purified by anotber $\mathrm{CCl}_{4}$ extraction cycle, in which NavO $\mathrm{N}_{2}$ is used for the oxidation of $I^{-}$to $I_{2}$ and $\mathrm{NaHSO}_{3}$ is used for the reduction of $I_{2}$ to $I^{-}$. 
The lodine is finally precipitated as AgI for weighing and couriting. Contamination by other fission activities, including bromine, is negligible. The complete procedure, together with a discussion of the develogment work, is given below.

\section{Preparation and Standardization of Carrier}

Dissolve $13 \mathrm{~B}$ of reagent - grade $\mathrm{KI}$ in water containing a few milligrams of $\mathrm{NaHCO}_{3}$, and dilute to 1 liter. Tais solution contains $10 \mathrm{mg}$ of lodine per milliliter.

Pipet $5 \mathrm{ml}$ of the carrier solution into a beaker, add about $50 \mathrm{ml}$ of $\mathrm{H}_{2} \mathrm{O}$ and $1 \mathrm{ml}$ of $6 \mathrm{M} \mathrm{HNO}_{3}$, and heat nearly to boiling. Add $5 \mathrm{ml}$ of $0.1 \mathrm{M} \mathrm{AgNO}_{3}$ drop by drop with continuous stirring, digest the precipltate for about $1 \mathrm{~min}$, and fliter quantitatively on a weighed sinteredglass crucible with suction. Wash three times with $5 \mathrm{ml}$ of $\mathrm{H}_{2} \mathrm{O}$ and three times with $5 \mathrm{ml}$ of 95 per cent ethanol, rinsing down the inside of the crucible with each portion of the wash liquid. Wipe the outside of the crucible dry and place in an oven at $110^{\circ} \mathrm{C}$ for $10 \mathrm{~min}$. Cool in a desiccator and welgh as ABI.

\section{Procedure}

step 1. Add to the sample of fission products (containing not more than $5 \mathrm{~g}$ of uranyl nitrate) in a $60-\mathrm{ml}$ separatory funnel about $10 \mathrm{ml}$ of $2 \mathrm{M} \mathrm{Na} \mathrm{NaO}_{3}$ (Note $I$ ) and $2 \mathrm{ml}$ of $\mathrm{I}^{-}$carrier. Add $1 \mathrm{ml}$ of 5 per cent NaC10, mix well (Note: It is desirable to give the NaClo time to oxidize radioiodine species fully, or better to heat), and acidify the solution by slowly adding $3 \mathrm{ml}$ of conc. $\mathrm{HNO}_{3}$. Add $3 \mathrm{ml}$ of $\mathrm{IM} \mathrm{NH} 2 \mathrm{OH} . \mathrm{HCl}$, and extract the $\mathrm{I}_{2}$ into $10 \mathrm{ml}$ of $\mathrm{CCl}_{4}$. Discard the aqueous layer.

Step 2. Shake the $\mathrm{CCl}_{4}$ layer with $10 \mathrm{ml}$ of $\mathrm{H}_{2} \mathrm{O}$ containing a few drops of IM $\mathrm{NaHSO}_{3}$ until both phases are colorless, and discard the $\mathrm{CCl}_{4}$.

Step 3. Add $1 \mathrm{ml}$ of $6 \mathrm{M} \mathrm{HNO}_{3}$ and a few drops of $1 \mathrm{M} \mathrm{NaNO}_{2}$, extract the $I_{2}$ into $10 \mathrm{ml}$ of $\mathrm{CCl}_{4}$, and discard the aqueous layer.

Step 4. Repeat step 2.

Step 5. Add $1 \mathrm{ml}$ of $6 \mathrm{M} \mathrm{HNO}_{3}$, and heat nearly to boiling (Note 2). Add $2 \mathrm{ml}$ of $0.1 \mathrm{M} \mathrm{AgNO}_{3}$ drop by drop with stirring, and digest the precipitate of AgI for a few seconds by gentle boiling and brisk stirring (Note 3). Filter with suction onto a weighed filtex-paper disk (Note 4) in a small Hirsch funnel; wash three times with $5 \mathrm{ml}$ of $\mathrm{H}_{2} \mathrm{O}$ and three times with $5 \mathrm{ml}$ of ethanol. Dry at $110^{\circ} \mathrm{C}$ for $10 \mathrm{~min}$, weigh as AgI, and mount.

Notes. 1. Uranyl nitrate hexahydrate (either as the solid or in 
solution) is readily soluble in $\mathrm{Na}_{2} \mathrm{CO}_{3}$ solution by the formation of the carbonate complex. If there is much free acid in the uranyl nitrate, the addition of more $\mathrm{Na}_{2} \mathrm{CO}_{3}$ and gentle heating may be required to effect complete solution.

2. The solution is acidified and heated to expel $\mathrm{SO}_{2}$ which might interfere in the AgI precipitation.

3. Silver lodide tends to form both a milky suspension and large clumps of precipitate. The digestion procedure aids in coagulating the suspension and also in breaking up the large particles of precipitate.

4. The filter-paper disk is washed with ethanol and drled under the conditions of the procedure before the weighing.

\section{Discussion}

Previous methods of determining fission-iodine activities, involving the use of carriers ${ }^{2}$ in the form of $\mathrm{I}^{-}$and employing oxidation-reduction reactions in acid solution to obtain $I_{2}$ for separation by extraction, have been shown to give low and exratic yields, 46 evidently owing to incomplete interchange between the radiolodine and the carriers. The interchange tests on previous methods of lodine separation consisted in preparing a stock solution of $77 \mathrm{~h} \mathrm{Te}$, determining the $2.4 \mathrm{~h} \mathrm{I}$ daughter activity at equilibrium by counting an aliquot of the stock solution through sufficient aluminum to absorb the softer $\beta$ radiation of the $77 \mathrm{~b}$ Te, and comparing this activity with the $2.4 \mathrm{~h}$ I activity obtained by various methods of lodine separation. In these tests it was found that the earller methods did not effect either complete or reproducible interchange between radioactive iodine and carrier lodine. For example, the procecure Involving the addition of iodine carrier as $\mathrm{IO}_{4}^{-}$and reduction to $\mathrm{I}^{-}$with $\mathrm{NaHSO}_{3}$ in dilute acid solution was found to give incomplete separations of $2.4 \mathrm{~h} \mathrm{I}$ from the stock solution, varying from 65 to 95 per cent. From these interchange tests it was evident that the usual methods of lodine separation do not give a complete removal of radioiodine from fission material. 4,46

Work on the development of a procedure that would effect a fast and complete interchange of radioiodine with carrlex lodine was carried out, and a satisfactory method was found in the oxidation of $\mathrm{I}^{-}$to $\mathrm{IO}_{4}^{-}$by NcClO in an alkaline solution. This reaction was shown to give complete and rapid interchange 44 by the $2.4 \mathrm{~h}$ I tracer tests mentioned above and has been incorporated in the procedure described in this paper. The difficulty of working in an alkaline solution in the presence of $\mathrm{NO}_{2}^{++}$ has been circumvented by use of the carbonate complex to prevent precipitation of uranium. 
Separate tracer tests with various fission activities have not been made, but the procedure has been used in a great deal of work on shortlived lodine activities, 47 with no evidence of contamination by other Iission activities, including the most probable contaminent, bramine. Two separations from bromine are afforded in the procedure: one separation is given by the reduction to $\mathrm{Br}^{-}$with hydroxylamine while $\mathrm{I}_{2}$ is being extracted, and the other separation is given by the extraction of $I_{2}$ after oxidation with $\mathrm{HNO}_{2}$ (this does not oxidize $\mathrm{Br}^{-}$). Moreover, the longest-lived bromine activity in flssion with a significant yield is $2.4 \mathrm{~h} \mathrm{Br}{ }^{83}$; bence bromine activity is not present in fission-product solutions that are more than a day old.

The lodine procedure can be adapted readily to a tandem method determining lodine and bromine. In this case $\mathrm{Br}^{-}$carrier is also added in step 1 (see Sec. 3), oxidized to $\mathrm{BrO}_{3}^{-}$by the $\mathrm{NaClO}^{\circ}$ and reduced to $\mathrm{Br}^{-}$ by the hydroxylamine. The $\mathrm{I}_{2}$ is then extracted with $\mathrm{CCl}_{4}$, and the $\mathrm{Br}^{-}$ In the aquecus layer is oxidized to $\mathrm{Br}_{2}$ with $\mathrm{KMnO}_{4}$ and is extracted into CCl. The bromine can then be purified, as in the case of lodine (steps 2 and 4), by another $\mathrm{CCl}_{4}$ extraction cycle, in which $\mathrm{KMnO}_{4}$ is used in dil. $\mathrm{HNO}_{3}$ for the oxidation of $\mathrm{Br}^{-}$to $\mathrm{Br}_{2}$ and hydroxylamine is used for the reduction of $\mathrm{Br}_{2}$ to $\mathrm{Br}^{-}$. The bromine is precipitated as $\mathrm{Ag} B \mathrm{Br}$ for weighing and counting, 48,49 as in the case of iodine (step 5). The separation from iodine should be excellent, since $\mathrm{KMnO}_{4}$ oxidizes $\mathrm{I}^{-}$to $\mathrm{IO}_{3}^{-}$and thus prevents its extraction with $\mathrm{Br}_{2}$ and since hydroxylamine reduces $\mathrm{IO}_{3}^{-}$to $\mathrm{I}_{2}$ and prevents its extraction with $\mathrm{Br}^{-\infty}$.

PROCEDURE 16 - IODINE

Source - Katcoff, Dillard, Finston, Finkle, Seller and Sugarman, N.N.E.S., Vol. 9, Book 3, pp 1635

\section{Introduction}

The procedure presented in this paper was developed to separate iodine formed in the fission of uranium metal. Complete exchange of the radioiodine with carrier $I^{-}$is expected, since the iodine activity formed in uranium metal is in a highly reducing medium and therefore is almost certainly present as $\mathrm{I}^{-}$ion, which should exchange rapidly with $\mathrm{I}^{-}$carrier during solution of the metal in $12 \mathrm{M} \mathrm{HCl}$. After the uranium metal is completely dissolved, $U(I V)$ and $I^{-}$are oxidized to $\mathrm{UO}_{2}^{++}$and $\mathrm{IO}_{3}^{-}$with an excess of $\mathrm{KMnO}_{4}$. The $\mathrm{IO}_{3}^{-}$is then reduced to $\mathrm{I}_{2}$ with $\mathrm{NH} 2 \mathrm{OH} \cdot \mathrm{HCl}$ and is re- 
moved from the other f1ssion elements by distillation into a $\mathrm{NaOH}$ solution. The distillate is acidified, and $I_{2}$ is removed by extraction with $\mathrm{CCl}_{4}$. The $\mathrm{I}_{2}$ is removed from the $\mathrm{CCl}_{4}$ by shaking with aqueous $\mathrm{NaHSO}_{3}$ and is then purified by two more $\mathrm{CCl}_{4}$ extractions, in which $\mathrm{NaNO}_{2}$ is used for the oxidation of $I^{-}$to $I_{2}$ and $\mathrm{NaHSO}_{3}$ is used for the reduction of $I_{2}$ to $I^{-}$. The lodine is finally precipitated as $\mathrm{PaI}_{2}$ for weighing and counting.

\section{Procedure}

Step 1. Transfer a suitable sample of irradiated uranium metal to a distilling flask that contains $2 \mathrm{ml}$ of $\mathrm{KI}$ ( $\mathrm{I}^{-}$concentration of $10 \mathrm{mg} / \mathrm{ml}$ ) carrier. Add $60 \mathrm{ml}$ of conc. HCl to dissolve the metal. To the small residue of carbide and oxide that remains, add $40 \mathrm{ml}$ of $\mathrm{IM} \mathrm{NaNO}_{2}$ to complete the solution (Note 1 ). The exit tube of the distilling flask is extended into $20 \mathrm{ml}$ of $6 \mathrm{~N} \mathrm{NaOH}$ solution, and a slow stream of air is passed continuously through the solution during this step (Note 2).

Step 2. Add the NaOH from the trap to the solution in the distiliing Plask, and stir the solution. Refill the trap with $20 \mathrm{ml}$ of fresh $6 \mathrm{~N} \mathrm{NaOH}$. Add an excess of sat. $\mathrm{KnO}_{4}$ to the solution to oxddize $U(I V)$ and $I^{-m}$ to $\mathrm{UO}_{2}^{++}$and $\mathrm{IO}_{3}^{-}$. Add $1.5 \mathrm{M} \mathrm{NH} \mathrm{NH}^{\circ} \mathrm{HCl}$ slowly until the solution becomes light yellow, and then add $20 \mathrm{ml}$ more. Heat the solution to distill the $I_{2}$ into the NaOH solution.

Step 3. Acidify the distillate, and extract the $I_{2}$ with $10 \mathrm{ml}$ of $\mathrm{CCI}_{4}$. Discard the aqueous layer.

Step 4. Shake the $\mathrm{CCl}_{4}$ layer with $10 \mathrm{ml}$ of $\mathrm{H}_{2} \mathrm{O}$ containing a few drops of $1 \mathrm{M} \mathrm{NaHSO}$ until both phases are colorless, and discard the $\mathrm{CCI}_{4}$ layer.

Step 5. Add $1 \mathrm{ml}$ of $6 \mathrm{~N} \mathrm{HNO}_{3}$ and a few drops of $2 \mathrm{M} \mathrm{NaNO}_{2}$, extract the Ia into $10 \mathrm{mI}$ of $\mathrm{CCl}_{4}$, and discard the aqueous layer.

Step 6. Repeat step 4.

Step 7. Heat the aqueous layer and add slowly $2 \mathrm{ml}$ of $\mathrm{Pd}\left(\mathrm{NO}_{3}\right)_{2}$ (10 mg/ml) to precipitate $\mathrm{PdI}_{2}$. Filter with suction on a weighed filterpaper disk in a small Hirsch funnel, and wash three times with $5 \mathrm{ml}$ of $\mathrm{H}_{2} \mathrm{O}$ and three times with $5 \mathrm{ml}$ of ethanol. Dry at $110^{\circ} \mathrm{C}$ for $10 \mathrm{~min}$, welgh as $\mathrm{PQI}_{2}$, and mount.

Notes. 1. Under these condftions the $\mathrm{NaNO}_{2}$ does not liberate $I_{2}$. 2. Any vapors of $I_{2}$ or $\mathrm{HI}$ that may come over are caught in the $\mathrm{NaOH}$ solution. 


\section{Discussion}

Previous methods of determining fission-iodine activities have been shown to give low and erratic ylelds, evidently because of incomplete interchange between the tracer lodine and the carrier lodine ${ }^{50,51}$ The procedure descrlbed above was observed to give a fast and apparently complete interchange in the determination of the fission yield of $6.7 \mathrm{~b}$ I. The method is dependent, however, on the use of irradiated uranium metal dissolved in $\mathrm{HCl}$ and $\mathrm{NaNO}_{2}$ to provide complete interchange; it cannot be used on other fission-product sources. * The problem of complete interchange is avoided in this case, since the active lodine is in a reducing medium and is probably present as $I^{-}$Ion, which exchanges rapidly with $\mathrm{I}^{-}$carrier.

Contemination by otber fission activities, including bromine, is negligible. Separation from bromine is afforded in the procedure by reduction with $\mathrm{NH}_{2} \mathrm{OH} \cdot \mathrm{HCl}$ to $\mathrm{Br}^{-}$while the $\mathrm{I}_{2}$ is being extracted, and by the extraction of $\mathrm{I}_{2}$ after oxidation with $\mathrm{NaNO}_{2}$, which does not oxidize $\mathrm{Br}^{-}$. The chemical yleld for the procedure is approximately 60 per cent.

\section{PROCEDURE 17 - IODINE}

Source - R. Overstreet and L. Jacobson, N.N.E.S., Vol. 9, Book 3, pp 1638

Tellurium metal is fused on a copper target and is bombarded with deuterons in a bell jar in the cyclotron. The tellurium is dissolved in $6 \mathrm{~N}^{2} \mathrm{NO}_{3}$ and the solution is distilled. The distillate, containing the radioactive $13.0 \mathrm{~d} \mathrm{I}^{128}, 25 \mathrm{~m} \mathrm{I}^{128}, 12.6 \mathrm{~h} \mathrm{I}^{130}$, and $8.0 \mathrm{~d} \mathrm{I}^{131}$, is collected in $\mathrm{CCl}_{4}$, which is then washed three times with distilled water. sufficient $\mathrm{Cl}_{2}$ gas is added to the $\mathrm{CCl}_{4}$ to produce a definite yellow color, and the mixture is placed in direct sunlight for at least $1 \mathrm{hr}$. At the end of this period the $\mathrm{CCl}_{4}$ mixture is extracted with an excess of either $\mathrm{Na}_{2} \mathrm{SO}_{3}$ or $\mathrm{Na}_{2} \mathrm{~S}_{2} \mathrm{O}_{3}$ to give a solution of tracer lodine free of significant amounts of inactive lodine carrier.

\footnotetext{
*A procedure developed (Glendenin, Metcalf, Novey, and Coryell, N.N.E.S., Vol. 9, Book 3, pp 1629) for use with Irradiated uranyl nitrate is presented in N.N.E.S., Vol. 9, Book 3, pp 1625 by Glendenin and Metcelf (Procedure 15).
} 
Source - D. S. Ballantine, N.N.E.S., Vol. 9, Book 3, pp 1639

Stable tellurium is irradiated with pile neutrons to produce $25 \mathrm{~m}$ $\mathrm{Te}^{131}$ and $30 \mathrm{~h} \mathrm{Te}^{232 \mathrm{~m}}$ by the $(\mathrm{n}, \gamma)$ reaction; the radioactive tellurium then decays to $8 \mathrm{~d} \mathrm{I}^{131}$. After a sultable decay period the radioactive lodine is oxidized to $\mathrm{IO}_{3}^{-}$during the solution of the irradiated tellurlum sample in a mixture of $18 \mathrm{~N} \mathrm{H}_{2} \mathrm{SO}_{4}$ and 50 per cent $\mathrm{CrO}_{3}$ in a 2 to 1 proportion. The $\mathrm{I}^{131}$ activity, after the reduction of $\mathrm{IO}_{3}^{-}$to $\mathrm{I}_{2}$ by the addition of axallc acid, is separated from the tellurium by distillation into a trap containing dil. NaOH. The general features of this method were suggested by I. L. Chaikoff.

An alternative source of $\mathrm{I}^{131}$ is the $\mathrm{HNO}_{3}$ condensate from the dissolution of neutron-activated uranium metal. The reduction of the lodine in the $\mathrm{HNO}_{3}$ solution is not practical because the NO evolved carries with it much of the lodine. The lodine is separated from $\mathrm{HNO}_{3}$ by oxldizing all the active lodine to $\mathrm{IO}_{3}^{-}$, in which state $1 t$ is not volatile, and removing the $\mathrm{HNO}_{3}$ by distillation. The oxidation is performed in a mixture of $18 \mathrm{~N} \mathrm{H}_{2} \mathrm{SO}_{4}$ and 50 per cent $\mathrm{CrO}_{3}$ in a 2 to 1 proportion. The $\mathrm{IO}_{3}^{-}$ is then reduced to $I_{2}$ with oxalic acid and is removed from the other fission elements by distillation.

\section{Separation of $I^{131}$ from Tellurium}

After the Irradiation of elementary tellurium in the pile and a suitable delay (to allow the $30 \mathrm{~h} \mathrm{Te} \mathrm{e}^{131 \mathrm{~m}}$ to decay to $\mathrm{I}^{131}$ ), the sample is placed in a distillation flask equipped with a reflux condenser. To this are added $18 \mathrm{~N} \mathrm{H}_{2} \mathrm{SO}_{4}$ and 50 per cent $\mathrm{CrO}_{3}$ in a 2 to 1 proportion, and the mixture is digested on a steam bath for $1 \mathrm{hr}$. (A 15-g sample requires about $100 \mathrm{ml}$ of $\mathrm{H}_{2} \mathrm{SO}_{4}$ and about $50 \mathrm{ml}$ of $\mathrm{CrO}_{3}$ solution.) In this step the teliurium is dissolved and the radioactive lodine is oxddized to $\mathrm{IO}_{3}{ }^{-}$. After the solution has been allowed to cool to room temperature, about 50 to $60 \mathrm{~g}$ of oxal1c acid and 50 to $75 \mathrm{ml}$ of $18 \mathrm{~N}$ $\mathrm{H}_{2} \mathrm{SO}_{4}$ are added. A reaction starts slowly, but soon there is frothing, and the reaction becomes vigorous for a minute or more. If sufficlent oxallic acid has been added, the solution will turn from a dark-brown color to a dark-green color as the chromate is reduced to chromic ion. If the solution is not definitely green, more oxalic acid should be added.

When the reduction is complete, the actual distillation of the lodine is begun. The apparatus consists of the original flask used in 
PROCEDURE 18 (Cont'a)

the dissolving step, a condenser, a recelving vessel, and a trap containing dif. NaOH. Any vapor that fails to condense in the condenser is bubbled through the NaOH trap so that none of the lodine can escape.

The progress of distillation can be observed by placing a directreading radiation meter under the receiving vessel and observing the increase in radiation intensity as the lodine is distilled. About 60 per cent of the total activity can be obtained in the first 15 or $20 \mathrm{mI}$ of the distillate. This first distillate is approximately $0.01 \mathrm{M}$ in $\mathrm{H}_{2} \mathrm{SO}_{4}$, as measured by titration with standardized $\mathrm{NaOH}$, and less than $0.001 \mathrm{~N}$ in reducing agents, as determined by titration with standardized permanganate solution. The solid materials usually total about 2 to $3 \mathrm{mg}$, and the radiochemical purity exceeds 99 per cent.

Further distillation will yield 25 to 30 per cent more of the totel Iodine, but this is obtained slowly and in a volume of 100 to $200 \mathrm{ml}$. This can be concentrated, however, by making the distillate basic with $\mathrm{NaOH}$ and heating to dryness, then acidifying with $\mathrm{H}_{2} \mathrm{SO}_{4}$ and oxalic acid and redistilling. The yield on this second distillation runs about 90 per cent in a volume of about $20 \mathrm{ml}$. Thls distillate is about $0.05 \mathrm{~N}$ to $0.1 \mathrm{~N}$ in $\mathrm{H}_{2} \mathrm{SO}_{4}$ but is similar to the first distillate in that it is about $0.001 \mathrm{~N}$ in reducing agents and contains only a few milligrams of solid material.

To date, the largest amount of tellurium that has been used is a 50-g sample. This 50-g sample at saturation, followed by 2 days of decay, yielded 75 millicuries in the first distillate and about 30 millicuries in the second distillate. By correcting for decay it was found that, at the time the tellurium was removed from the pile, the total iodine produced amounted to about 125 millicuries.*

\section{Recovery of $I^{231}$ from $\mathrm{HNO}_{3}$ Solution}

When neutron-activated uranium metal is dissolved in hot conc. $\mathrm{HNO}_{3}$ and the fumes are condensed, the solution, about $10 \mathrm{~N}$ in $\mathrm{HNO}_{3}$ is found to contain an appreciable fraction of the fission-iodine activity together with traces of iron and chromium from the stainless-steel equipment. Reduction of the lodine to the elementary state and extraction with

\footnotetext{
*Editors ${ }^{*}$ Note: Independent study of the same type of procedure is reported in detail by A. W. Kenny and W. T. Spragg (J. Chem. Soc., 1949: S323).
} 
PROCRDURE 18 (Cont'd)

$\mathrm{CCl}_{4}$ is not practical. For easy handling, the $\mathrm{HNO}_{3}$ is distilled off while the iodine is maintained in the iodate state.

The $\mathrm{HNO}_{3}$ condensate is placed in a distilling flask equipped with a condenser and a receiving vessel. One-to-one $\mathrm{H}_{2} \mathrm{SO}_{4}$ and 50 per cent $\mathrm{CrO}_{3}$ are added in 2 to 1 proportion until the characeristic dark chromate color is obtained. The mixture is then distilled to remove all the $\mathrm{BNO}_{3}$ until white fumes of $\mathrm{H}_{2} \mathrm{SO}_{4}$ appear. The solution is then cooled, and about $10 \mathrm{~g}$ of oxalic acid and about $25 \mathrm{ml}$ of $18 \mathrm{~N} \mathrm{H}_{2} \mathrm{SO}_{4}$ are added to recuce all the $\mathrm{CrO}_{3}$. This mixture is distilled in the manner described above. About 80 per cent of the total activity is thus obtained in a volume of $25 \mathrm{ml}$. This distillate is about $0.05 \mathrm{~N}$ to $0.1 \mathrm{~N}$ in $\mathrm{H}_{2} \mathrm{SO}_{4}$ and less than $0.00 \mathrm{NN}$ in reducing agents, and it contains only a few milligrams of solid material. The radiochemical purity is more than 99 per cent. 


\section{REFERENCES}

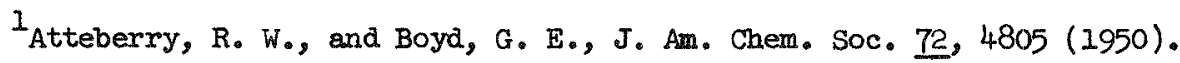

'Rieraan, W., and Lindenbarm, S., Anal. Chem. 24, 1199 (1952).

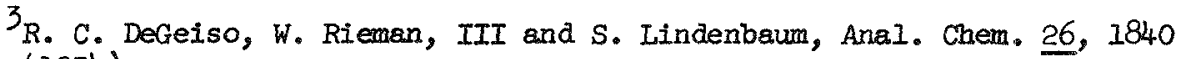
(1954).

${ }^{4}$ R. Kunin, Record Chem. Prog. 15, 85 (1954).

5. I. Khomlev and L. I. Tsimbalista, Zhur. Anal. Khim. 8, 217 (1953).

${ }^{6}$ C. Teige, Mem. Soc. roy. lettres et scin. Classe sci., No. 5 (1949: Chem. Abs. 48, 5022 (1954).

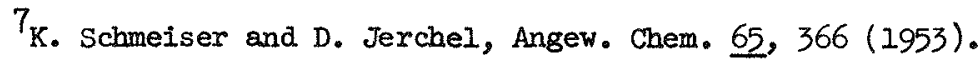

Zipkin, I., Armstrong, W. D., Singer, L., Anal. Chem. 29, 310 (1957).

${ }^{9}$ Coursier, J., Saulnier, J., Anal. Chim. Acta 14, 62 (1956).

10 Amphlett, McDonald and Redman, J. Inorg. Nucl. Chem. 6, 236 (1958).

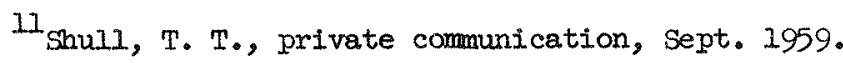

12 A. C. Jahl and N. A. Bonner, Radioactivity Applied to Chemistry, Table

$8 \mathrm{~A}$, p. 466, John Wiley and Sons, New York (1951).

$13 \mathrm{~J}$. F. Cosgrove, R. P. Bastian, and G. H. Morrison, Anal. Chem. 30, 1872 (1958).

${ }^{14}$ K. D. Moffett, J. R. Simmler, and H. A. Potratz, Anal. Chem. 28, 1356 (1956).

${ }^{15}$ Hillebrand, et al, Applied Inorganic Analysis, John Wiley and Sons, p. 741 (1953).

16 H. H. Willard and O. B. Winter, Ind. Eng. Chem. Anal. Ed., 2, 7 (1933).

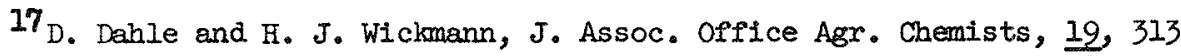
(1936); 20, 297 (1937).

18 F. A. Gooch and F. W. Mar, Am. J. Sci. [3] 39, 293 (1890). 
${ }^{19}$ F. A. Gooch and H. J. Cole, Am. J. Sci. [4] 37,257 (1914).

200. E. Myers and R. J. Prestwood, In Radio activity Applied to Chemistry,

A. C. Wahl and N. A. Bonner, Editors, John Wiley and Sons, Inc., New York, 1951, pp. 28-29.

$21_{R}$. Halford, J. Am. Chem. Soc. 62, 3233 (1940).

22 R. R. Edwards and H. Gest, Nat'I. Nuclear Energy Series, Div. IV., Radiochemical Studies: The Fission Products, 1454 (1951).

23 H. Taube and H. Dodgen, J. Am. Chem. Soc. II, 3330 (1949).

24.F. A. Long and A. R. Olson, J. Am. Chem. Soc. 58, 2214 (1936).

${ }^{25}$ D. A. Lee, J. Am. Chem. Soc. 76,2590 (1954).

26I. M. Kolthof, et al., J. Am. Chem. Soc. 61, 3409, 34.14 (1939); 76, $1503(1954)$

27 R. H. Betts and A. N. MacKenzie, Can. J. Chem. 29, 655 (195I).

${ }^{28}$ R. R. Edwards, H. Gest and T. H. Devies, ref. 3, p. 237.

29 W. H. Burgus and T. H. Devies, ref. 3, g. 209.

30 M. Cottin, M. Haissinsky and D. Peschanskt, J. Chim. Phys. 48, 500 (1951).

31. E. Myers and J.W. Kennedy, J. Am. Chem. Soc., 72, 897 (1950).

32 R. E. Connick and Z. Z. Hugus, Jr., Brookhaven Conf. Rept. BNL-C -8 , Isotopic Exchange Reactions and Chem. KInetics, Chem. Conf. No. 2, 164 (1948).

33 L. E. Glendenin, R. P. Metcalf, T. B. Novey and C. D. Coryell, ref. 22, p. 1629.

34.E. L. Brady and G.W. Campbell, N.N.E.S., Vol. 9, Book 3, pp. 1449

${ }^{35}$ R. R. Edwerds, H. Gest, and T.H. Davies, ibid, Book 1, pp. 237

36 L. E. Glendenin, Report CC-920, Sept. 15, 1943.

37 A. Langsdorr and E. Segre, Phys. Rev., 57: 105 (1940)

${ }^{38}$ R. R. Edwards, H. Gest, and T. H. Davies, N.N.E.S., Vol. 9, Book I, pp 237.

${ }^{39}$ R. R. Edwards and T. H. Davies, Ibid, pp 255.

40 D. C. DeVauIt and W. F. Libby, J. Am. Chem. Soc, 63, 3216 (1941)

4II. M. Kolthoff and A. S. OBgrien, J. Am. Chem. Soc., 6I, 3409, 3414 (1939).

42 E. H. Swift, A System of Chemical Analysis, "Prentice-Hall, Inc., New York, 1939.

${ }^{43}$ G. W. Campbell and E. I. Brady, N.N.E.S., Vol. 9, Book 3, pp 1623. 
44 L. E. Glendenin, R. P. Metcalf, T. B. Novey, and C. D. Coryell, ibid, pp 1629.

45 S. Katcoff, B. Finkle, and N. Sugarman, Report CC-1331, Feb. 7, 1944. 46 S. Katcoff, C. R. Dillard, H. Finston, B. Finkle, J. A. Seiler, and N. Sugarman, N.N.E.S., Vol. 9, Book 2, pp 1005.

47. E. Glendenin and R. P. Metcalf, N.N.E.S., Vol. 9, Book 2, pp 992. $4^{48}$ E. L. Brady and G. W. Campbell, N.N.E.S., Vol. 9, Book 3, pp 1449.

49 I. E. Glendenin, R. R. Edwards, and H. Cest, ibid, pp 1451.

50.T. B. Novey and C. D. Coryell, private communication, 1944.

${ }^{51}$ L. E. Glendenin and R. P. Metcalf, N.N.E.S., Vol. 9, Book 2, pp 992.

52 Katcoff, Dillaxd, Finston, Finkle, Seiler, and Sugarman, ibid, Book 2, pp 1005. 